\title{
A SOCIOLINGUÍSTICA MUSICAL BRASILEIRA
}

\section{ARTIGO ORIGINAL}

MALDONADO, Gabriel Orlando Quiñones ${ }^{1}$

MARTÍNEZ, Clara Coleta Oropeza ${ }^{2}$

MALDONADO, Gabriel Orlando Quiñones. MARTÍNEZ, Clara Coleta Oropeza. A sociolinguística musical brasileira. Revista Científica Multidisciplinar Núcleo do Conhecimento. Ano 05, Ed. 02, Vol. 04, pp. 93-130. Fevereiro de 2020. ISSN: 24480959

Link

de

acesso: https://www.nucleodoconhecimento.com.br/educacao/sociolinguistica-

musical

\section{RESUMO}

Este artigo é resultado de anos experiência e contato com o ensino do português do Brasil e com as reflexões oriundas de uma pesquisa de pós-doutoramento. Nesta pesquisa, há informações relevantes sobre o ensino do português do Brasil como língua estrangeira e as diversas necessidades apresentadas por ex-alunos de Porto Rico. O questionário foi utilizado para investigar se havia algum problema entre a comunidade de ex-alunos. O problema apresentado pelos ex-alunos foi a falta de um

1 Doutor em Ensino da Língua Portuguesa pela Bircham Internacional University em Madrid Espanha (2018); Mestre em Línguas, Culturas e Sociedades em Ambientes Multilíngues - Francês Língua Estrangeira pela “Université des Antilles” em Martinica (M1-2016 / M2-2018); Pós-graduado (Especialização) em Estudos de Língua Portuguesa: Investigação e Ensino pela Universidade Aberta de Portugal (2014): Graduado em Línguas Modernas, habilitação em Português e Francês, pela Universidad de Puerto Rico - Recinto de Río Pedras (2009).

2 Orientadora de Pós-doutorado - Universidad Virtual de Estudios Superiores, Guadalajara México. 
curso lúdico de música brasileira, que, por sua vez, precisa integrar todos os componentes essenciais para o aprendizado avançado do português, como: linguística e suas variantes e a sociedade e cultura. As necessidades encontradas na investigação foram compiladas com base nas respostas dos alunos de português do Brasil em Porto Rico. Dados da neurociência revelaram a conexão indiscutível que existe entre os dois hemisférios cerebrais: o lógico e o holístico em paralelo. Proceder à solução do problema com a criação do curso de sociolinguística musical brasileira para atender às necessidades dos futuros alunos do programa de português foi um dos objetivos do trabalho. Pretende-se, ainda, que a pesquisa sirva como base científica para a implementação do curso.

Palavras-chave: Cultura e sociedade brasileira, didática do português brasileiro, música brasileira, linguística portuguesa, sociolinguística musical brasileira, variações linguísticas do português brasileiro.

\section{INTRODUÇÃO}

A educação é um processo contínuo e sempre em movimento. O progresso na educação é tão rápido que não podemos mover-nos em um ritmo lento. Não devemos permitir a estagnação por falta de recursos, treinamento profissional ou disposição. Nossa era traz uma ampla gama de fatores e elementos com os quais devemos trabalhar para alcançar uma integração bem-sucedida na tendência educacional do século XXI. Em algumas áreas, devemos priorizar a efetiva integração de transformações. Este é o caso da nossa população de aprendizes do português brasileiro em Porto Rico. No ensino-aprendizagem de línguas, existem muitas técnicas e recursos que podem ser usados para enriquecer as habilidades de comunicação oral, compreensão oral, expressão escrita, compreensão leitora e a interação com o português brasileiro.

É importante cobrir todas as competências essenciais para o desenvolvimento da linguagem, num ambiente real de imersão na sociedade brasileira. O problema encontrado nesta investigação foi a falta de um curso lúdico de música brasileira, no qual foram integrados todos os componentes essenciais para o aprendizado avançado 
do português, como: a linguística e suas variantes, a sociedade e sua cultura. Nesta problemática apresenta-se a necessidade de ter acesso a um tratamento específico do conhecimento da linguística, das variações linguísticas, da sociedade e da sua cultura. Assim, o ensino-aprendizagem avançado do português brasileiro, da linguística e suas variantes, da sociedade e sua cultura abarcariam as situações formais que ocorrem na sala de aula em contextos formais e apropriados com os diferentes recursos empregados no dia a dia no desenvolvimento do curso.

A função da língua de estabelecer contatos sociais e o papel social, por ela desempenhado de transmitir informações sobre o falante constitui uma prova cabal de que existe uma íntima relação entre língua e sociedade (...). A própria língua como sistema acompanha de perto a evolução da sociedade e reflete de certo modo os padrões de comportamento, que variam em função do tempo e do espaço (MONTEIRO, 2000, p. 16-17).

Isto ajudaria o aluno a ter uma boa competência comunicativa em qualquer região ou estado do Brasil. É algo essencial, também, para que o aluno possa usar seu conhecimento acerca da diversidade cultural existente no país. O método a ser utilizado no curso visa que o aluno também seja capaz de entender e praticar a diversidade cultural de cada país de língua portuguesa, entretanto, neste caso, a ênfase se concentra na diversidade brasileira. Isso permite que ele aprenda, ao mesmo tempo, os conceitos acadêmicos dos diferentes temas e desenvolva a competência comunicativa necessária e que possa interagir social e culturalmente em um ambiente agradável, sem ter prejuízo pelo desconhecimento do funcionamento linguístico, social e cultural do povo brasileiro.

\section{MARCO CURRICULAR}

\subsection{A LINGUÍSTICA E SUAS VARIAÇÕES}

O objetivo desta pesquisa é analisar os benefícios da inclusão de aprendizes no processo de ensino-aprendizagem de variedades linguísticas no campo da 
compreensão oral de sotaques do português brasileiro. Nosso sistema social permite a interação frequente com outros países que podem introduzir variações na aprendizagem no estudo de línguas. As variações linguísticas são a cultura e a sociedade de um povo. Precisamos conhecer essa variedade para evitar confusão em futuras interações entre falantes nativos e pessoas que estudaram a mesma língua estrangeira, mas com um sotaque diferente.

Existem dialetos nacionais: o português do Portugal é, por exemplo, diferente do português brasileiro. Dentro das nações, existem diferenças de dialetos regionais: o modo de falar dos cariocas é claramente diferente do dos gaúchos ou dos paulistas. Dentro das comunidades, existem diferenças entre diferentes grupos populacionais: entre urbano e rural, entre pessoas de diferentes origens sociais e educacionais, entre grupos étnicos, entre grupos etários, homens e mulheres (GUY; ZILLES, 2006, p. 42).

Reconhecendo que existe essa variedade dialetos em um mesmo território é importante, ao ensinar a língua portuguesa, demonstrar, aos aprendizes, a variabilidade da língua, sobretudo os diferentes modos de se falar nas regiões distintas do país, e, também, a pluralidade de significados que uma mesma palavra pode possuir, a depender da região em que esse aluno-aprendiz se encontra.

\subsection{VARIAÇÃO DIATÓPICA}

Deixando de lado qualquer tipo de esclarecimento do conceito de linguagem, este tipo de variedade é relativo ao locutor de acordo com sua origem territorial. Essas variedades são tradicionalmente chamadas de "dialetos". De fato, este termo referese à diversidade das formas de expressão da linguagem e aos domínios nos quais ela é usada. O estudo dessas variedades inclui dialetos e dialetos locais. As considerações sociais dos fatos linguísticos da linguagem, compreendidas como um sistema linguístico caracterizado por uma forte diferenciação, são definidas com muita direção, sendo promovidas como uma importante tradição literária e, às vezes, impõem vários significados linguísticos derivados de uma mesma fonte. Assim, as 
duas características essenciais da linguagem pertencem à um grau suficiente de diferenciação de outros sistemas linguísticos e à uma estrutura composta de características em comum com variações geográficas, sociais e pessoais.

Num dado momento (por exemplo, na primeira década deste século), a língua portuguesa não é falada exatamente da mesma maneira por todos os indivíduos que a têm como língua materna. Essa variação resulta de vários fatores. Uma variação diatópica (ou variação geográfica ou variação regional) refere-se às diferentes maneiras de falar de assuntos com uma dada linguagem natural de acordo com as áreas geográficas em que vivem. Existe uma variação diatópica em uma linguagem natural que reflete expressões de pessoas que usam a linguagem em seus diferentes modos de uso, por razões que surgem da região onde moram e onde nasceram e cresceram (para o acervo da variedade de idioma desta região é chamada de variedade geográfica). Estritamente falando, não é a geografia que determina as diferentes formas de falar uma linguagem natural, mas a dispersão espacial de falantes de uma língua que contribui para as comunidades que falam essa língua, que têm diferentes comportamentos linguísticos (SILVA, 2010, p. 239).

É essencial que se mantenha em mente que a língua nunca será falada da mesma forma por todos os indivíduos de uma comunidade, aqui, no caso, a comunidade de falantes do português-brasileiro. Essa variação é derivada dos mais diversos fenômenos linguísticos que possuem caráter linguístico, regional, de gênero, de faixa etária bem como responde aos aspectos sociais, culturais e econômicos que fazem parte do cotidiano desse falante. A linguagem se tornará natural a depender da região na qual se encontra esse indivíduo, assim, ao entrar em contato com falantes de outras regiões, irá se deparar com a riqueza linguística do português brasileiro.

\subsection{VARIAÇÃO DIASTRÁTICA}

Muitos linguistas ligaram o estudo da linguagem às características dos diferentes grupos que compõem a sociedade. Para eles, existe uma estreita relação entre a 
linguagem e o ambiente social em que ela é usada. Todas as línguas têm variedades determinadas pela variedade social, e, dessa forma, os sujeitos são condicionados por fatores como, por exemplo, a classe à qual as pessoas pertencem, educação, ocupação, situação econômica etc. Os resultados dessa variedade diatópica apontam que falantes da mesma língua não falam da mesma maneira, pois a região geográfica em que vivem e/ou o lugar de sua origem influenciam nesse falar. Até mesmo os moradores que residem em uma determinada região podem não falar exatamente da mesma maneira. Por exemplo, os moradores que residem ou são do norte de Portugal não falam da mesma maneira.

Os seres humanos vivem em sociedades que atingiram muita complexidade, particularmente no que diz respeito à organização de grupos profissionais e sociais. Muitas diferenças no uso da linguagem vêm da profissão que uma pessoa tem ou dos contatos privilegiados que tem com pessoas de um determinado grupo sócio profissional. Cada grupo sócio profissional tem suas próprias características; por exemplo, em relação ao nível de educação dos membros do grupo, as realidades a que estão expostos diariamente no decorrer de sua atividade etc. A variação linguística que resulta da natureza sociocultural dessas propriedades é chamada de "variedade diastrática". De maneira simplista, a variação diastrática é identificada pelo fato de um advogado não fala do mesmo jeito do que um engenheiro de computação, um mecânico, um cantor de ópera, um oftalmologista ou um jornalista esportivo (SILVA, 2010, p. 251).

Considerando este contexto é possível perceber que esse tipo de variação pode ocorrer, também, em função da ocupação profissional de um indivíduo. Assim, caso este venha a desempenhar uma outra atividade, em um primeiro momento, pode não conseguir utilizar as expressões típicas da nova profissão. Essa diferença na atualização de uma língua é estudada na sociolinguística. Assim, como o nome sugere, a sociolinguística usa conceitos e métodos da sociologia e da linguística para explicar seu objeto de estudo. É, portanto, "uma disciplina que está na fronteira entre 
dois campos de estudo que visam analisar a influência dos contextos sociais nos usos linguísticos" (SILVA, 2010, p. 251).

\subsection{VARIAÇÃO DIAFÁSICA}

Não se fala da mesma maneira com os amigos como em uma conferência ou em um ambiente profissional: no primeiro caso, uma variante de estilo ou dialeto é usada e, no segundo, um estilo ou uma variante formal. Portanto, a variação diafásica depende dos seguintes fatores: o sujeito (formal, especializado) ou de questões envolvidas na comunicação falada. $\mathrm{O}$ estilo usado é diferente entre um comentarista esportivo e um astrólogo que envia mensagens específicas. Outro tipo de variação linguística é a variedade diáfana que deriva de dois fatores: a natureza individual da situação, que é uma situação de comunicação prática em que um falante é inserido e do modo individualizado, cujo cada falante usa a linguagem de um modo específico.

Aqui estão alguns exemplos que mostram os fenômenos da variação diafásica em uma situação de comunicação pode ser considerado com base em um conjunto de fatores que interferem com a produção de sujeitos verbais que são inseridos nele: o grau de formalidade ou o informal situação, o tema da conversa, o lugar onde ocorre, a idade dos atores, seu status social e o tipo de relação que eles têm entre eles (mais família) são exemplos de fatores que determinam o que nós dizer. Uma conversa entre amigos em um futebol café é caracterizada por um nível informal, o que contrasta com a formalidade inerente a um discurso do Presidente da República sobre o estado da nação, à Assembleia antes de os deputados e membros do governo. A cuidadosa seleção das palavras e sua pronúncia, com a construção sintática e articulação do conteúdo, geralmente observada no discurso político, opõe-se à atitude mais descontraída dos amigos em uma conversa sobre um assunto cotidiano. A má escolha de palavras, a pronúncia incorreta ou a construção sintática deficiente geralmente não são embaraçosas entre os amigos em uma situação de comunicação informal. Mas a mesma 
coisa não pode ser dita em uma situação de formalidade e solenidade (SILVA, 2010, p. 259).

Esse tipo de variação se manifesta, principalmente, no nível lexical e sintático, na medida em que se relaciona tanto com as escolhas lexicais do falante quanto com as construções sintáticas que ele usa com mais frequência. Às vezes, no entanto, o falante também é susceptível de ser reconhecido foneticamente, sobretudo no processo de articulação dos sons da linguagem. Em todos esses casos, estamos lidando com uma variação diafásica (ou uma pessoa ou situação).

\section{A SOCIEDADE E A CULTURA}

A humanidade aprendeu a evoluir, ao longo do tempo, a partir de muitas estratégias de sobrevivência, sendo que a mais distinta é a adaptação. A adaptação permitiu que os sujeitos seguissem seu próprio caminho, mesmo nos lugares mais difíceis de viver e sobreviver, das maneiras mais complexas. Um elemento que acompanha a estratégia de adaptação e regulação progressiva nas diferentes regiões do planeta é a dimensão simbólica. Esta abrange crenças, rituais, significados, conceitos ideológicos, identidades etc. Em suma, abarca uma ampla gama de fios que tecem o que é chamado de cultura. A linguagem, por sua vez, toma forma a partir de elementos da comunicação, da troca de códigos, dos símbolos, dos significados e das ideologias. Este tem sido um refletor muito eficaz quando se trata de investigar o que tem estado na mente e a realidade de uma sociedade.

A cultura analisada a partir da dimensão social deve ser enfatizada no ensino e aprendizagem de normas culturais. Valores são comportamentos aceitáveis de um dado grupo social e são algumas das normas culturais que o indivíduo deve ser educado para que possa fazer parte da sociedade. Tudo o que foi aprendido desde a infância é automaticamente internalizado, e, assim, esse aprendizado modela o comportamento que deve ter enquanto cidadão, seja no cotidiano ou no trabalho. Ao acomodar modelos externos impostos, a pessoa pode se relacionar com os outros e entender seu ambiente. Isso fornece uma segurança psicológica que resulta na 
integração da cultura circundante. A diversidade cultural, uma herança comum da nossa humanidade, assumiu muitas formas ao longo do tempo e do espaço.

Essa diversidade se manifesta na peculiaridade e multiplicidade de identidades dos grupos sociais que compõem a humanidade. Os princípios do intercâmbio, da inovação e criatividade e da diversidade cultural são, para a espécie humana, os mais importantes, assim como a biodiversidade é para a natureza. Nesse sentido, determinam o patrimônio comum da humanidade que deve ser registrado e afirmado para o benefício das gerações presentes e futuras. A diversidade cultural aumenta as chances de desenvolvimentos mais amplos em áreas importantes para a sociedade, como, por exemplo, o desenvolvimento intelectual, emocional, moral e espiritual. A diversidade cultural e os direitos humanos protegem a diversidade cultural, e, assim, são exigências éticas para que haja o respeito à dignidade humana.

Cada pessoa assume a responsabilidade de respeitar os direitos humanos e as liberdades fundamentais, sobretudo os direitos das pessoas pertencentes as minorias e aos povos indígenas. Ninguém pode incentivar a diversidade cultural a minar os direitos humanos garantidos pelo direito internacional ou restringir sua acessibilidade. Todo ser humano pode se expressar e mostrar seu trabalho na língua que ele quer, especialmente em sua língua materna. Toda pessoa tem direito a uma aprendizagem e treinamento de qualidade que respeite absolutamente sua identidade cultural, e, assim, qualquer indivíduo pode fazer parte da vida cultural que desejar e expressar suas próprias práticas culturais, desde que haja o respeito aos direitos humanos e as liberdades fundamentais.

A diversidade cultural deve ser acessível a todos. A liberdade de expressão, a multiplicidade dos meios de comunicação, o multilinguismo, a igualdade disponível para as expressões artísticas, o conhecimento científico e tecnológico são princípios que devem ser iguais para todas as culturas, devendo, portanto, estar presentes nos meios de expressão e difusão, a fim de garantir que a diversidade cultural esteja latente na sociedade. As diferentes criações estão enraizadas em tradições culturais, mas florescem em contato com outras culturas. Por esta razão, a herança, em todas as suas variedades, deve ser preservada, fortalecida e transferida para as gerações 
futuras como prova dos costumes, tradições e aspirações dos seres humanos, a fim de aumentar a criatividade em toda a sua diversidade e estabelecer um verdadeiro parlamento entre culturas.

É importante respeitar e preservar os métodos tradicionais de conhecimento, principalmente aqueles ensinados pelos povos indígenas bem como é preciso avaliar a contribuição do conhecimento tradicional para a proteção do meio ambiente e gestão dos recursos naturais, sendo essencial, então, promover a conexão entre a ciência moderna e a expertise de cada ramo do conhecimento, sobretudo neste momento em que a globalização impõe desafios comuns à biodiversidade, à diversidade cultural e à ligação entre as duas esferas.

Muitas comunidades demandam materiais, de forma frenética, e, assim, impedem a auto conservação cultural, sobretudo em razão do estouro de potências estrangeiras, dos estereótipos de produtos, das imagens, da fortuna e da modernidade. As principais indústrias de energia que querem se destacar lideram o maior problema enfrentado por todos os países. A diversidade cultural e a biodiversidade estabelecem títulos de longo prazo. A diversidade cultural é uma fiadora que procura expandir-se para o bem-estar da natureza, e, assim, pleiteiam uma sociedade em que os seres humanos das gerações futuras possam viver de forma saudável. É válido mencionar, sobre diversidade e criatividade a longo prazo, que:

Na amostra de países de referência, os Estados Unidos oferecem um exemplo particularmente ilustrativo, uma vez que o tratamento político da diversidade cultural e de identidade supera amplamente os programas públicos destinados a reduzir as desigualdades econômicas e sociais. As demandas multiculturais são ainda mais prósperas, porque as políticas sociais são reduzidas ao mínimo. A atratividade dos recursos da comunidade está, então, diretamente relacionada ao desmantelamento gradual dos programas sociais e às diferenças nos padrões de vida entre os vários componentes da população (Constant, 2000). 
Um dos principais pontos é proteger o patrimônio linguístico da humanidade e apoiar a educação e a aprendizagem em quantas línguas for possível. Isso nos permite promover e ensinar a diversidade linguística sem deixar de lado a importância da língua materna em todos os níveis de ensino. Ensinar e aprender múltiplos idiomas é encorajado a partir do nível elementar. Destina-se a destacar e sensibilizar, a partir da educação, sobre o valor inestimável da diversidade cultural e, para que, assim, seja possível desenvolver programas e realizar o treinamento de professores de escolas e universidades. O manejo frutífero das culturas na escola também significa a consciência dos aprendizes e de todos os atores dessa diversidade latente e esses não devem ser submetidos a novas formas de categorização, mesmo as "positivas", que envolvem e formatam identidades individuais e coletiva (Akkari, 2013).

A variação linguística é considerada como um conjunto de características linguísticas que possui diferentes ocorrências e que, frequentemente, refletem sobre um dialeto em um contexto linguístico. Qualquer variação linguística sistemática de uma língua específica é falada em uma zona, em uma região ou em um mesmo grupo social. A variação linguística, geralmente, coincide com as barreiras geográficas, sociais e políticas. As pessoas, frequentemente, mudam suas residências e trazem seus dialetos para outros países. A chegada de ferramentas comunicativas favoreceu a generalização da variedade da linguagem padrão, que coexiste com as mais divergentes, criando, dessa forma, condições de diglossia.

A pronúncia não é uniforme em todos os povos, e, assim, a diferenciação interna da sociedade é refletida na linguagem e pode mascarar os traços dialetais, criando-se, então, a variação linguística, seja ela interna, social, geográfica, local ou internacional. Os riscos que impedem a comunicação podem ser causados por várias razões. Para evitar essa eventualidade na sala de aula, é preciso que o professor promova um clima de confiança bem como deve haver proximidade com a variante de idioma. A variação linguística pode ser positiva ou negativa para estudantes estrangeiros, dependendo de vários fatores, como as habilidades do aluno, a situação familiar e pessoal, o ambiente sociocultural que os envolve e a metodologia aplicada. Por exemplo, se uma 
escola escolhe integrar as culturas/diversidade de estudantes, não pode deixar de dar alguma legitimidade à língua materna desses alunos.

O próximo passo é encontrar o equilíbrio certo entre a linguagem comum de instrução e a abertura para as línguas nativas dos alunos. No entanto, na mente de alguns atores escolares, integração significa o uso exclusivo da língua do país anfitrião (Akkari, 2013). A educação de qualidade é necessária para toda a população, e, dessa forma, precisa contar com uma abordagem holística para preservar a diversidade da educação universal. Embora tenhamos progredido, o sistema educacional ainda classifica os alunos com base no desempenho acadêmico e os estratos sociais estão em melhor posição para obter os melhores pontos ou percentuais. É preciso tomar cuidado com essas pontuações, pois elas podem acabar acarretando situações de desvantagem para os alunos, os impedindo de aprender.

\section{A INTEGRAÇÃO DE MÚSICA E VIDEOS MUSICAIS}

O desenvolvimento da linguagem oral no estudo de línguas estrangeiras é de extrema importância, pois é a ferramenta que vai permitir que os alunos tenham uma aprendizagem bem-sucedida. A linguagem oral permite a comunicação entre as pessoas, e, quando desenvolvida, é uma ferramenta útil de socialização, pois, ao mesmo tempo, é usada para atender às necessidades básicas, para expressar sentimentos e para regular a apreciação da língua-alvo. A fim de desenvolver a expressão oral, ensina-se o padrão fonológico, morfossintático, lexical e semântico, isto é, é ensinado, aos alunos, os aspectos pragmáticos do discurso oral: como fazer pausas, como questionar, como intervir em debates etc. É preciso compreender, então, a linguagem oral como uma ferramenta que codifica o pensamento.

Devido a tal caráter, a oralidade ajuda a organizar a reflexão e a conceituação acerca de diversidades temáticas, fazendo com que seja possível falar dos objetos e situações da vida cotidiana na língua-alvo. Segundo Pombo (2007), a própria competência de expressão oral melhorou, dado que as TIC trouxeram novas potencialidades à aula de Língua portuguesa, pois permite que os professores gravem e escutem as manifestações dos alunos bem como a fazer leituras sobre seus 
comentários. A compreensão auditiva é uma habilidade que os alunos devem praticar com muita frequência, porque é um procedimento muito importante para adquirir outras aprendizagens. As abordagens atuais dão importância a alguns exercícios específicos e atividades de compreensão auditiva para trabalhar as diversas habilidades. Esses exercícios devem ser frequentes e breves.

O aluno precisa de muita prática para desenvolver a habilidade de ouvir e esses exercícios deverão ser combinados com exercícios de expressão oral. O material para o trabalho deve ser variado e real (gravações reais de linguagem, contexto dos alunos, erros e hesitações desses alunos etc.). Além disso, o professor deve apresentar diferentes dialetos ou registos para que se acostumem a ouvir diferentes tipos de linguagem. Os alunos têm que ter uma razão para ouvir, e, portanto, antes de iniciar a conversa, é preciso introduzir o assunto e os aspectos sobre os dados e questões a serem trabalhadas em sala de aula. Também deve avaliar o resultado junto com os alunos. O desenvolvimento da expressão oral requer prática constante, e, por isso, temos que incentivar a elaboração de atividades frequentes e variadas, estabelecendo um propósito claro para que o aluno conheça esses dialetos.

O aprendizado da expressão oral pode ser realizado a partir de várias opções, tais como: atividades que possuem curta duração (alguns minutos) e atividades a serem desenvolvidas em sessões de aprendizagem para que haja o desenvolvimento pleno da linguagem. $O$ objetivo dessa estratégia é chamar a atenção para habilidades específicas de expressão oral para que sejam reforçadas de maneira progressiva. Isso exige que os alunos saibam, claramente, o que estão aprendendo (identificar partes importantes, identificar a finalidade da emissora, controle de voz, aguardar a sua vez etc.). O que importa, em qualquer caso, é a forma como o estudante expressa ou compreende o texto. As tecnologias de gravação de áudio e vídeo permitem que os alunos possam dizer frases, praticar línguas ou realizar diversas atividades orais etc.

A música é uma ferramenta essencial para o desenvolvimento das habilidades linguísticas no aprendizado de línguas estrangeiras. Ela pode trazer, ao aluno, mais fluidez nos processos de compreensão e expressão oral, e, ainda, faz com que o aluno, finalmente, aos poucos, perca 0 medo de falar na língua-alvo. A 
conceptualização é uma das operações mentais necessárias para que a aprendizagem ocorra. A tarefa do professor é o fornecimento de materiais adequados e a promoção de situações, atividades e jogos para desenvolver esta capacidade, 0 que não é construído, mas é feito de forma consciente e metodicamente. O QECR referido por Dias e Bidarra (2010), trata-se de "oportunidades de prática". É um componente da oralidade bastante positivo, pois há ênfase nas atividades de compreensão, produção e interação com a língua oral (DIAS, 2010).

Os vídeos musicais são recursos de áudio ideais, sendo, então, excelentes para o ensino de uma segunda língua, uma vez que não só permitem, aos alunos, ouvir as palavras pronunciadas por falantes nativos, mas também permite-lhes assistir e comparar a diversidade de gêneros em contraste com a sociedade e a cultura. Segundo Dias e Bidarra (2010), a metodologia passa pela interrelação de vários fatores que integram situações comunicativas realizadas por falantes nativos a partir da seleção de documentos do cotidiano, da diversidade tipológica de exercícios e atividades com graus de dificuldade distintos e da flexibilidade para colocar em prática tais atividades (DIAS, 2010).

Nesse contexto, é possível perceber que os meios de comunicação de áudio podem atuar como uma alternativa estimulante para ler e ouvir o professor, visto que há a apresentação de mensagens verbais de forma mais dramática do que o texto escrito, o que pode chamar mais a atenção do aluno. Com um pouco de imaginação da parte do professor, o áudio pode ser muito versátil, e, também, dinâmico, devido as muitas possibilidades de uso. Segundo Franco (2010), o Voki é um serviço gratuito e on-line que permite a criação de personagens virtuais. É possível adicionar mensagens de voz a partir da gravação por microfone, converter o texto para áudio e é possível fazer uso de um arquivo de som já existente.

\section{DIDÁTICA DA CONCEPTUALIZAÇÃO}

Existem diferentes habilidades para adquirir conhecimento, o que complica conhecer, de forma detalhada, os processos de ensino-aprendizagem. De certa forma, é, também, um sinal de esperança para modificar e adaptar métodos. Há oportunidades 
para alcançar uma compreensão oral da língua padrão, mas a forma como conceituamos a compreensão oral das variedades linguísticas também pode se expandir a partir da realização de diferentes gravações de áudio em língua portuguesa. É mais provável que a compreensão autêntica apareça e se torne aparente para os outros se as pessoas tiverem várias habilidades para representar um conceito e puderem mudar facilmente de uma linguagem padrão para uma linguagem sustentável.

Não se pode esperar que alguém tenha todas essas habilidades, mas todos podem ter, pelo menos, algumas habilidades para representar o conceito de variedade linguística em língua portuguesa, para que haja, assim, uma compreensão oral adequada dos sotaques do português brasileiro. A utilização de diferentes métodos para o ensino de língua portuguesa ou estrangeira não é exigida nas escolas públicas do Ministério de Educação de Porto Rico. Atualmente, o Ministério segue as regras do quadro comum de línguas estrangeiras, mas não exige o uso de nenhum método em particular, o que deixa os professores de língua estrangeira livres. O Ministério da Educação de Porto Rico estabeleceu como padrão para o ensino de línguas estrangeiras, em algumas escolas especializadas, que deve haver uma educação individual, especializada, personalizada e útil para o desenvolvimento das línguas estrangeiras. Entretanto, o modelo ainda não foi aderido por todas as escolas.

Segundo Ruíz e Zambrano (2014), isso se deve ao fato de os professores não utilizarem com frequência estratégias de ensino e aprendizagem para o processamento da metacognição e para o desenvolvimento da leitura e escrita. Isso também pode se dar devido ao fato de que os professores ainda estão ligados ao uso de métodos tradicionais, o que acarreta a falta de conhecimento e experiência para a implementação dos procedimentos propostos para o ensino de leitura e escrita para os alunos. É comum ouvir o termo "didática" quando se fala de indivíduos que estão relacionados à educação, ao ensino de processos ou às sociedades dedicadas a criar ferramentas para o desenvolvimento intelectual e cognitivo dos aprendizes. Usamos a palavra "didática" quando falamos sobre questões relacionadas a materiais 
educacionais e à criação de atividades para crianças ou produtos destinados a colocar tais atividades em voga.

Mas, em muitas das vezes, nos perdemos em repetições diárias sem realmente entender a definição teórica do conceito de "didática". Para apreender os processos de aplicação e dominar o tema da conceituação didática, deve-se reconhecer que é um ramo da pedagogia que se dedica a auscultar processos e técnicas para obter modelos específicos de ensino mais apropriados para se chegar ao conhecimento. Além disso, o professor deve alcançar de forma positiva e eficaz todos os alunos, independentemente dos fatores sociais, culturais e econômicos, e, ainda, deve priorizar a diversidade de aprendizagem. A didática representa todas as disciplinas que se concentram nos diferentes métodos de aprendizagem que permitem, aos alunos, passar pelo processo de análise, planejamento e abordagem de suas próprias técnicas de aprendizagem.

A didática é um processo aplicável a todas as questões necessárias para atender às necessidades intelectuais, emocionais e sociais de cada indivíduo. É a mesma prática de interação que o aluno cria com as habilidades e conceitos educacionais. A didática é a arte da educação. Uma pessoa que é educada pode, então, compreender vários conceitos importantes, como, por exemplo, os valores universais, as atitudes, os conflitos sociais, a diversidade cultural, a valorização da arte e do esporte, tentando, dessa forma, produzir ideias-chave e processos que compõem esta arte de ensinar. Ao longo dos anos, a partir da integração de diferentes estratégias de ensino, como, por exemplo, com a tecnologia, com as artes plásticas, com o acesso direto às comunicações e com as contribuições positivas de pessoas de fora da educação, as referências didáticas foram modernizadas.

Agora, mais do que nunca, este método visa elevar os princípios da educação eficaz e flexível para que os professores possam escolher o conteúdo certo para apoiar modelos de ensino e aprendizagem em ambientes educacionais de forma a receber alunos de diferentes origens e inteligências e a partir de estilos diversos de aprendizagem. Para garantir esse ensino didático, existem três elementos de considerável importância: o professor (que leciona), o aluno (quem aprende) e o 
conteúdo da aprendizagem (o que é ensinado). A combinação desses três fatores de aprendizagem é muito relevante, sustentável e formal, a fim de poder transportar a educação para lugares fora do ambiente escolar e aplicá-la ao cotidiano de cada indivíduo. Soto (2013) cita um filósofo porto-riquenho, Eugênio Maria de Hostos, e, assim, afirma que "não basta ensinar conhecimento, é preciso aprender a adquiri-lo".

O que foi feito cientificamente não é suficiente, é necessário aprender a treiná-lo. Não é suficiente combinar o ensino com um único método. É necessário aprender a administrá-lo. Em suma, não basta aprender, há necessidade de ensinar o raciocínio. A didática da conceptualização é o processo de aquisição de conhecimento, e, assim, contempla os diferentes aspectos dos assuntos acadêmicos e a sua transmissão adequada. Howard Gardner, um psicólogo americano, desenvolveu, em 1983, a teoria das inteligências múltiplas. Segundo Gardner (1997), a inteligência é a capacidade que temos para resolver problemas cotidianos ou para fornecer serviços no campo da cultura em si. Para Gardner (1997), essa é uma habilidade que é, em parte, geneticamente marcada, mas pode se desenvolver. Nossas capacidades podem ser reforçadas de uma forma ou outra, dependendo do contexto da mídia, de nossos costumes, da educação que recebemos etc. As inteligências múltiplas são as seguintes:

- Inteligência interpessoal (com os outros): entender os sentimentos, necessidades e objetivos dos outros;

- Inteligência visual / espacial: a criação e interpretação de imagens, pensamentos tridimensionais;

- Inteligência interpessoal (em si): entender os pensamentos e emoções interiores muito claramente;

- O corpo e a inteligência cinestésica sentem e expressam uma forma corporal, realizam seu trabalho manualmente;

- Inteligência lógico-matemática: raciocínio, raciocínio lógico, problemas de gestão matemática;

- Inteligência linguística verbal: usar o uso da linguagem para expressar ideias, sentimentos ou persuadir os outros; 
- A inteligência naturalista: entender os modelos, a classificação e o comportamento da natureza;

- Inteligência musical: criando ou sentindo um ritmo, expressando um estado emocional, detectando ou analisando diferentes melodias.

A didática da conceptualização propõe elementos específicos para alcançar uma aplicação de excelência.

- O estudante: representa o fator mais importante nessa transferência educacional. Ele é o protagonista do processo de ensino-aprendizagem.

- O professor: representa uma figura de facilitador, guia, conselheiro do aluno. Deve ser um agente de mudança por excelência e deve manter, constantemente, uma rede de informação e estímulos positivos para colocar em prática os processos educacionais.

- Os objetivos: representam o guia do educador que orienta e direciona o processo educativo. As projeções permitem, a curto ou longo prazo, medir a implementação da educação.

- O conteúdo: a partir do conteúdo os objetivos propostos pelo professor são alcançados.

- O material pedagógico: representa qualquer tipo de dispositivo de projeto ou desenvolvimento que mantenha a intenção de facilitar, contribuir, auxiliar ou fornecer acesso ao processo de ensino-aprendizagem. Os materiais didáticos representam as ferramentas utilizadas pelos professores para viabilizar 0 processo de transferência de conhecimento.

- Técnicas e métodos de ensino: representam as estratégias de ensino adotadas para influenciar todos os alunos. Técnicas e métodos de ensino devem ser projetados para atender às necessidades educacionais de cada setor, população e estudante.

\section{COMPREENSÃO ORAL}

A compreensão oral é fundamental para os estudantes portugueses em Porto Rico. Eles podem diversificar e obter posições sociais onde se sintam competentes para ter 
sucesso. Além disso, eles podem ser capazes de funcionar livremente, oferecendo a qualidade da compreensão oral dentro e fora de seu país de origem. Ao ouvir e falar, é importante examinar e levar em conta a linguagem não verbal para perceber o significado completo do que se quer expressar. De acordo Pascual et al (2014), a importância de ouvir é fundamental, como é a habilidade cognitiva que permite a passagem de leitura oral na descriptografia de leitura como fonte de aprendizado. Portanto, a aspiração atual de que todos os alunos alcancem um alto domínio da linguagem escrita não é um desafio e oferecem treinamento explícito sobre a melhoria da compreensão oral para todo o ensino primário.

As diferentes habilidades foram suplantadas pela tecnologia. Para as crianças, ler, ouvir, analisar ou aplicar o aprendizado com o ensino tradicional não é mais atraente. Telefones celulares, tablets, computadores, jogos eletrônicos e outras tecnologias oferecem um entretenimento confortável, o que chama a atenção desses aprendizes, e, dessa forma, desenvolver a compreensão oral em línguas estrangeiras e enfatizar as variantes linguísticas são processos essenciais no ensino-aprendizagem. Para que os alunos sempre considerem a oferta da universidade como uma opção, nossas escolas propuseram integrar a tecnologia ao processo de ensino.

Essa tentativa de melhorar a qualidade da educação também pode afetar o sucesso geral. Badia et al (2016), discutem sobre a relação positiva e significativa entre benefícios percebidos em relação à tecnologia pelos professores bem como o uso frequente de dessas nas salas de aula. Agora é difícil saber que relação pode ser estabelecida entre os benefícios percebidos para a tecnologia e o tipo de uso da tecnologia para o ensino e a aprendizagem. Esse desafio é ainda maior se examinarmos essa relação em ambientes educacionais com acesso limitado à tecnologia, cujos professores ainda estão em treinamento para colocar esses recursos tecnológicos em prática no contexto educacional. 


\section{METODOLOGIA DE INVESTIGAÇÃO}

\subsection{ENVOLVIDOS NA INVESTIGAÇÃO}

Quadro 1: Envolvidos no estudo

\begin{tabular}{|l|l|}
\hline População & Estudantes pesquisados \\
\hline Ex-alunos que frequentaram o & Ex-alunos que mostraram o interesse \\
português como língua estrangeira em ter estudado um curso que \\
em Porto Rico. & $\begin{array}{l}\text { integrasse os aspectos sociais, culturais } \\
\text { e linguísticos do português brasileiro. }\end{array}$ \\
\hline
\end{tabular}

Fonte: Elaborado pelo autor (2020)

\subsection{OS OBJETIVOS DO PROJETO DE INVESTIGAÇÃO}

- Comprovar a necessidade dos ex-alunos de ter estudado um curso que integrasse os aspectos sociais, culturais e linguísticos do português brasileiro;

- Reconhecer os benefícios do uso da música como ferramenta do ensinoaprendizagem dos aspectos sociais, culturais e linguísticos do português brasileiro;

- Identificar estratégias de ensino para conceituar a competência para que sejam aplicadas aos aspectos sociais, culturais e linguísticos do português brasileiro;

- Criar ferramentas de ensino musical aplicáveis ao ensino-aprendizagem dos aspectos sociais, culturais e linguísticos do português brasileiro;

- Treinar professores para atender estudantes de português como língua estrangeira, com ferramentas que facilitam o ensino-aprendizagem dos aspectos sociais, culturais e linguísticos do português brasileiro;

Ao trabalhar com estudantes de português em Porto Rico, espera-se que os resultados sejam alcançados a partir de um ensino eficaz. Se sabemos que os números dos alunos pesquisados nos dão um ponto de partida específico, também devemos considerar as suas emoções e os seus sentimentos para elaborarmos as 
atividades. Estes resultados fornecem detalhes para que os professores sejam capazes de colocar em prática ações adequadas para a implementação de um curso lúdico e diferente, de forma a integrar os aspectos sociais, culturais e linguísticos do português brasileiro.

\subsection{TIPO DE DADOS PARA COLETAR}

Foi utilizado um questionário como método de pesquisa para a coleta de impressões e reações de ex-alunos de português em Porto Rico. Este método de coleta faz com que seja possível analisar, diretamente, as necessidades existentes dos ex-alunos que não tiveram um curso lúdico e diferente que integrasse os aspectos sociais, culturais e linguísticos do português brasileiro. Esta ferramenta de pesquisa oferece dados quantitativos específicos que poderão ser usados para desenvolver algumas metas e objetivos para satisfazer as necessidades dos futuros alunos.

\subsection{POSSÍVEIS RESULTADOS}

Prevê-se que este método de pesquisa qualitativo e quantitativo seja aplicado a exalunos para investigar se existiu alguma necessidade nessa população estudantil. Em segundo lugar, queremos mostrar, quantitativamente, que há essa necessidade especial no ensino-aprendizagem dos aspectos sociais, culturais e linguísticos do português brasileiro. Por último, com estes dados oficiais, a pesquisa buscará mostrar que o programa deve ser adaptado como merece para que seja possível responder as necessidades educacionais e para que haja o desenvolvimento igualitário e significativo de futuros alunos.

\subsection{RECOLHA, PROCESSAMENTO E ANÁLISE DE DADOS}

Ao empregar este método de investigação, é preciso que ele desempenhe um papel expressivo para coletar dados objetivos e reais sobre as necessidades dos alunos. Todos os indivíduos são medidos da mesma forma e com a mesma ferramenta. Os dados foram reunidos em um banco de dados para que não houvesse uma margem de dúvida no processo de coleta, processamento e análise de dados. O uso de 
observações quantitativas é uma boa ferramenta para coletar, processar e analisar dados, visto que fornece resultados oportunos. Com este sistema de coleta de dados, não há a pressão ou a imposição para que os pesquisadores adotem ações que podem não contribuir para com uma coleta real das necessidades dos alunos.

A partir da obtenção dos dados quantitativos, foi possível analisar, de forma detalhada, as necessidades apontadas por um grupo composto por trinta e cinco (35) ex-alunos de língua portuguesa na cidade de Porto Rico. O questionário apresenta várias preguntas, e, a partir delas, obteve-se impressões e dados acerca das necessidades dos pesquisados. O gráfico 1 evidencia o método de pesquisa usado para coleta, processamento e análise de dados. Destacamos, na pesquisa, as perguntas e as respostas para analisar os resultados a partir de gráficos que refletem a existência de nosso problema de pesquisa: a importância da música para ensinar a língua portuguesa.

Gráfico 1: Linguística e as suas variantes

1. Quanto você sabe da linguística do português e suas variantes?

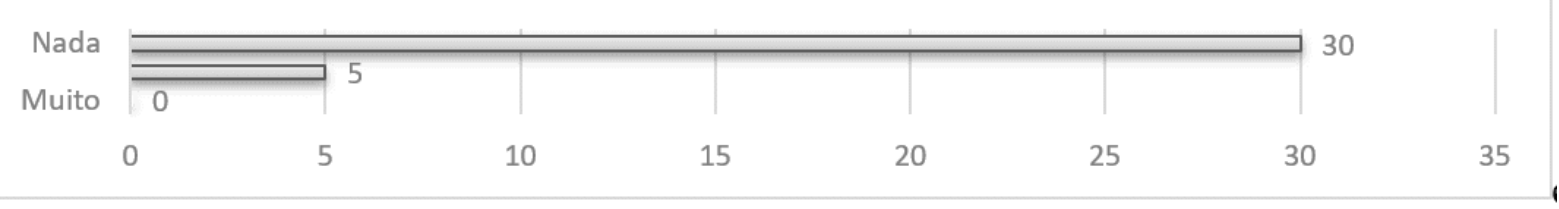

Fonte: Elaborado pelo autor (2020)

O gráfico 1 mostra a análise dos dados coletados, e, dessa forma, apresenta e detalha o desconhecimento dos 35 alunos sobre o termo da linguística do português e suas variantes. Isso nos revela, novamente, a importância da abordagem da temática do ensino das variantes da língua portuguesa. Prosseguindo, há o gráfico 2. Este tem como objetivo refletir, segundo a percepção dos ex-alunos, se os sujeitos brasileiros possuem o mesmo sotaque. 
Gráfico 2: Sotaques da língua portuguesa

2. Os seres humanos falam uma língua com o mesmo sotaque?

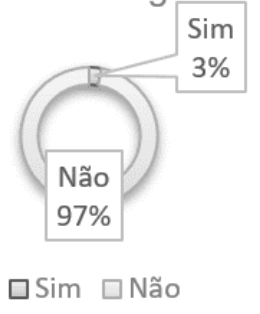

Fonte: Elaborado pelo autor (2020)

O gráfico 2, por sua vez, revela que, dentro da amostra escolhida, $97 \%$ dos ex-alunos acreditam que os seres humanos não falam a mesma língua. Essa diversidade da língua portuguesa pode, portanto, ser explorada em sala de aula a fim de que se compreenda que existe uma pluralidade de formas de se falar e de conceituar uma mesma palavra em língua portuguesa. O gráfico 3, por conseguinte, teve como objetivo refletir sobre os fatores que podem fazer com que os sotaques de uma língua se modifiquem.

Gráfico 3: Fatores que influenciam na modificação dos sotaques

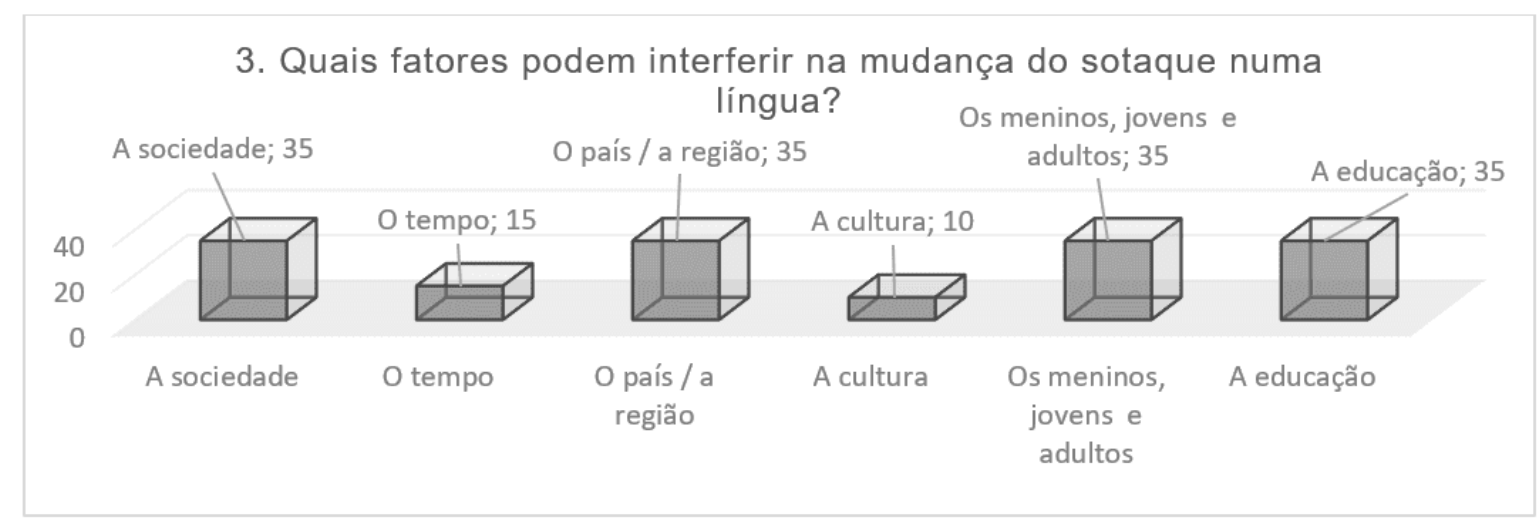

Fonte: Elaborado pelo autor (2020)

O gráfico 3 revelou que os alunos entrevistados acreditam que existe uma variedade de fatores que podem interferir na mudança do sotaque duma língua, visto que $100 \%$ da amostra apontou que os fatores que interferem na mudança de um sotaque são: a 
sociedade a região, o contexto familiar, o contato com jovens e adultos e o contexto educacional. Prosseguindo, o gráfico 4 questionou, aos entrevistados, se esses fariam um curso de língua portuguesa que integre os aspectos sociais e culturais aos linguísticos.

Gráfico 4: Integração de aspectos sociais e culturais no ensino de língua portuguesa

4. Você estudaria um curso que faça a integração dos aspectos sociais, culturais e linguísticos do português brasileiro?

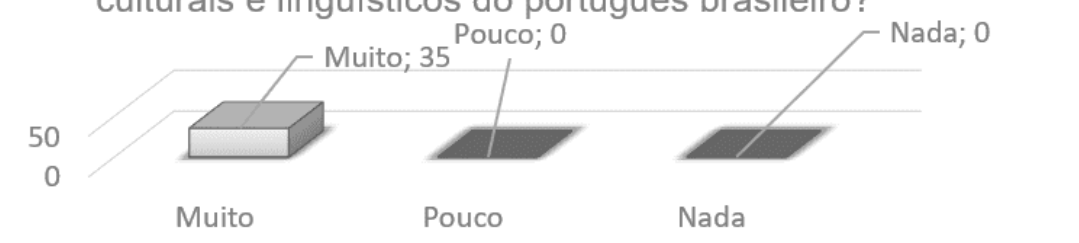

Fonte: Elaborado pelo autor (2020)

Os resultados apontam que $100 \%$ dos alunos fariam um curso de língua portuguesa que integra os aspectos sociais, culturais e linguísticos, visto que isso enriquece e torna o aprendizado mais dinâmico. O gráfico 5 , por sua vez, teve como objetivo avaliar se esses ex-alunos acreditam que teriam um melhor desenvolvimento no processo de aprendizado da língua portuguesa se os aspectos culturais e sociais fossem abordados de forma proporcional aos elementos linguísticos da língua portuguesa.

Gráfico 5: O desenvolvimento social, cultural e linguístico no aprendizado

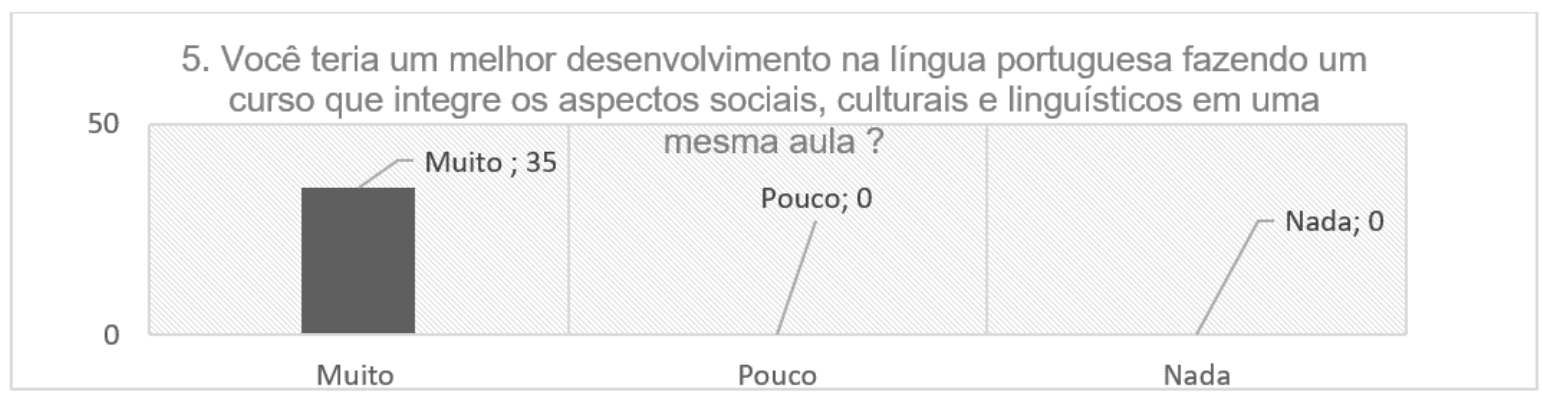

Fonte: Elaborado pelos autores (2020) 
O gráfico 5 revelou que $35 \%$ da amostra acredita que os alunos poderiam ter uma melhor compreensão oral na língua portuguesa se fosse, a eles, proposto um curso que integra os aspectos sociais, culturais e linguísticos em uma mesma aula. Posteriormente, questionou-se se esses ex-alunos acreditam que ferramentas tecnológicas o ajudariam a conhecer mais os aspectos sociais, culturais e linguísticos que englobam a língua portuguesa e as suas variantes.

Gráfico 6: Ferramentas tecnológicas no ensino de língua portuguesa

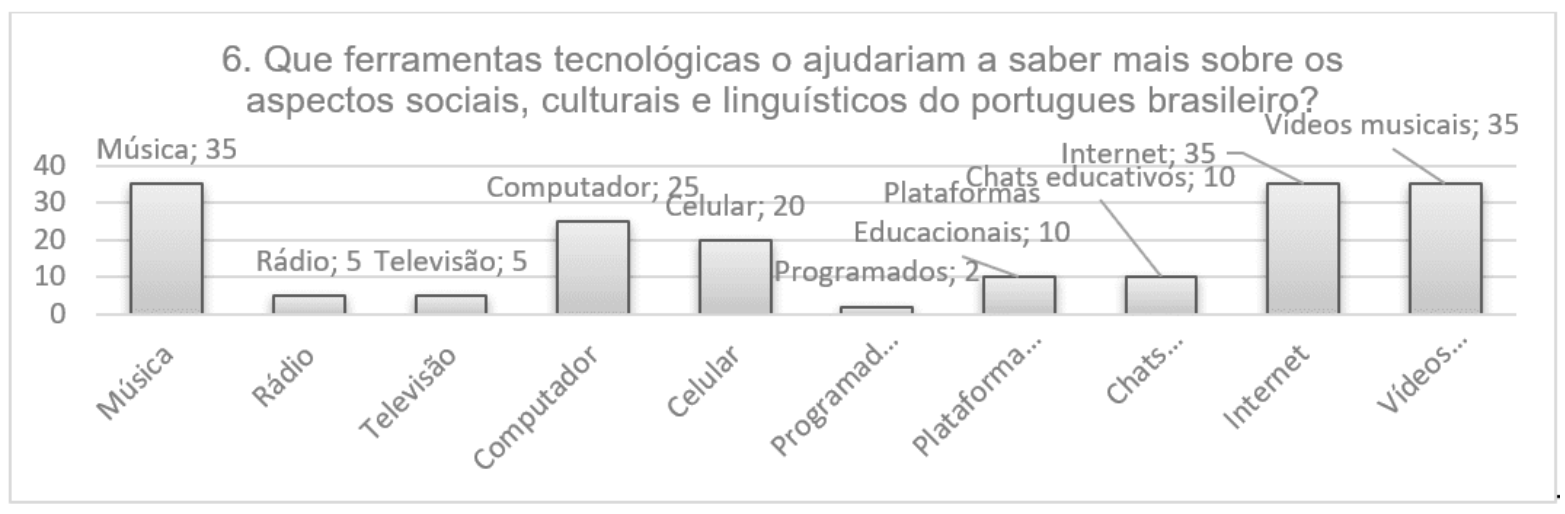

Fonte: Elaborado pelo autor (2020)

Os resultados apontam que todos os ex-alunos acreditam que as ferramentas tecnológicas os ajudariam a saber mais sobre os aspectos sociais, culturais e linguísticos do português brasileiro e 100\% da amostra aponta que a música, os vídeos musicais e a internet são as ferramentas mais interessantes para integrar esses aspectos, o que confirma a nossa hipótese inicial de que a música pode ajudar esses alunos a obterem uma melhor experiência ao entrarem em contato com a língua portuguesa. O gráfico 7, por sua vez, teve como objetivo perguntar, aos entrevistados, se a música e os vídeos musicais são relevantes para compreender os aspectos sociais, culturais e linguísticos do português brasileiro. 
Gráfico 7: A importância da música e dos vídeos musicais

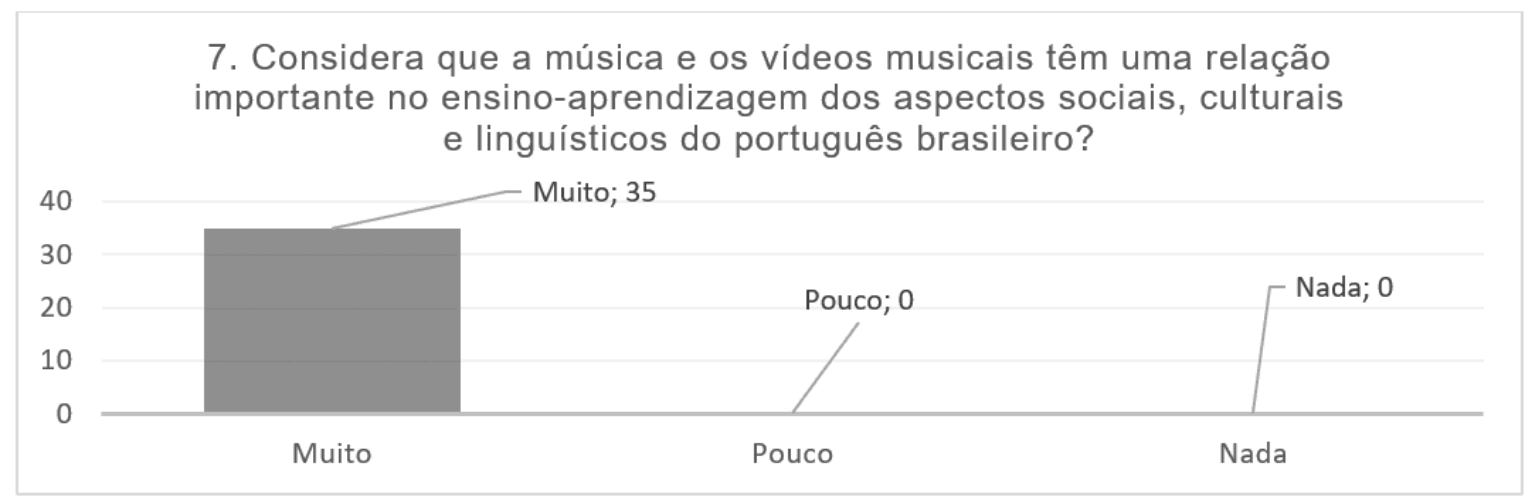

Fonte: Elaborado pelo autor (2020)

Os resultados apontam que $100 \%$ dos ex-alunos acreditam que é muito importante a relação da música e dos vídeos musicais com o ensino-aprendizagem dos aspectos sociais, culturais e linguísticos do português brasileiro. Por fim, os ex-alunos foram questionados se acreditam que é importante conhecer os aspectos sociais, culturais e linguísticos que dão forma ao português brasileiro.

Gráfico 8: Percepções sobre os aspectos sociais, culturais e linguísticos

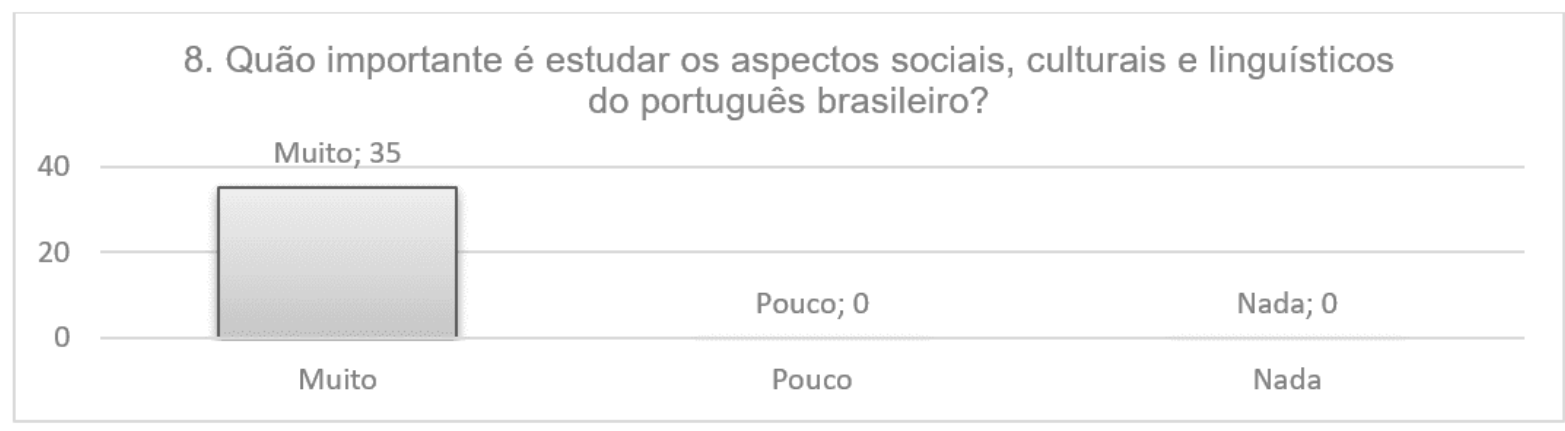

Fonte: Elaborado pelo autor (2020)

O gráfico 8 revelou que 100\% dos alunos entrevistados acreditam que estudar, de forma detalhada, os aspectos sociais, culturais e linguísticos do português brasileiro é de extrema importância. 


\section{ANÁLISE}

$\mathrm{Na}$ aquisição de uma língua estrangeira, trabalha-se com processos cognitivos e situações de aquisição. A posição behaviorista é, em princípio, como vimos, um bom método de aprendizagem que deve conduzir sem erros o estudo de cada assunto. A teoria behaviorista prevê a possibilidade de um universo de contingências reforçadoras, em princípio perfeitamente gerenciáveis, sujeitas a muitas circunstâncias aleatórias, porque "nada é perfeito". Esta teoria admite que as condições de aquisição são diferentes, especialmente em termos de motivação. Parte da interpretação da aprendizagem de línguas estrangeiras é a questão "Devemos ensinar sintaxe às crianças? ". Sua resposta é "não". Gaonac'h (1987) discute diferentes aspectos do objetivo de aquisição da linguagem de uma criança ou de um adulto, como, por exemplo, a sequência natural de aquisição ou a ordem natural de aquisição.

Essas são características cognitivas das situações de aprendizagem de línguas estrangeiras que defendem a teoria do mercado que, por sua vez, refere-se à multiplicidade de processos e à pluralidade dos níveis de desempenho das atividades de linguagem. Em um método de ensino existem variáveis relacionadas à personalidade do aluno que podem levar a uma abordagem da linguagem em que as atividades de produção são mal representadas. Como a situação escolar é particularmente favorável para o desenvolvimento de estratégias de evitação, aplicamos estratégias específicas como o ensino-aprendizagem de variedades linguísticas para a competência de compreensão oral. Em outras palavras, podemos ver que os modos de aquisição da linguagem não podem ser separados das atividades de linguagem envolvidas na situação.

No que diz respeito ao ensino-aprendizagem de línguas estrangeiras, a abordagem construtivista traduz-se numa atmosfera de classe sem ansiedade, em que a línguaalvo, o português, é utilizado para facilitar a comunicação entre os alunos e o professor, e, ainda, para que haja uma verdadeira comunicação e compreensão oral. Materiais linguísticos autênticos são usados para capturar a atenção, os valores e os interesses dos alunos. Alguns materiais podem ser criados pelos alunos para 
aumentar seu interesse e participação em cada nível da língua. Cooperar e trabalhar, em pequenos grupos, incentiva a aprendizagem e reforça o "feedback" construtivo entre os colegas. O ensino-aprendizagem de línguas por projeto é desenvolvido em sala de aula para todos os alunos e é usado para ajudá-los a aprender a ter uma atmosfera divertida.

Nesta pesquisa, o resultado do trabalho na sala de aula é muito importante para enriquecer e complementar o trabalho acadêmico do dia a dia, e, assim, conta com atividades extracurriculares que respondem aos interesses dos alunos e desenvolve as habilidades necessárias para que os alunos sejam transportados para a experiência de aprender uma língua estrangeira e as suas variações linguísticas. Os alunos trabalham com diferentes estratégias de aprendizagem e integram múltiplas inteligências que são consideradas e abordadas, enquanto outras são desenvolvidas por meio de uma variedade de técnicas, atividades e materiais de ensino apropriados. O português como língua estrangeira deve ser ensinado em um contexto sociolinguístico que não ameace o meio ambiente, reconhecendo que o espanhol é a língua materna dos estudantes.

A aprendizagem de línguas deve ser uma experiência gratificante para ampliar a mente e permitir atender sempre às crescentes demandas para se tornar profissionais em um mundo globalizado. O ensino apropriado da língua portuguesa para portoriquenhos ou outros falantes nativos de espanhol deve perseguir objetivos essenciais e usar materiais didáticos apropriados para o ensino-aprendizagem das variações linguísticas. A língua estrangeira não é apenas a língua de comunicação na sala de aula, mas também permite comunicar-se no ambiente escolar, viajar, divertir-se ou conseguir um bom emprego. $\mathrm{O}$ aluno deve ter um programa variado no qual possa estudar a linguística e suas variantes bem como a sociedade e a cultura. Nesta primeira fase, foi determinado o problema pela necessidade dos alunos. Pode-se encarregar de ensinar a partir de uma abordagem de ação e por meio da metodologia de ensino por processo.

Inicialmente, o foco se concentra nas funções requeridas para comunicação e compreensão oral das variações linguísticas por diferentes tipos de música que 
podem ser encontradas na Internet. Existem muitos vídeos de música e a música propriamente dita. Eles baseados nas habilidades necessárias para uma boa abordagem orientada para a ação no ensino-aprendizagem de variedades de línguas estrangeiras. Desenvolver sequências pedagógicas adequadas para trabalhar com a abordagem orientada para a ação de processos de ensino ou tarefas que serão muito importantes para aplicar na língua estrangeira, que, nesta pesquisa, não contemplam, apenas, as quatro habilidades essenciais, mas também o ensino de aprendizagem das variações linguísticas para uma boa compreensão oral dos sotaques do português brasileiro por meio da integração da música.

Em relação à metodologia, o ensino do português como língua estrangeira pode e deve utilizar várias estratégias previamente recomendadas para o ensino do português como primeira língua. Estratégias como educação cooperativa, diferenciação de programas e trabalho com múltiplas inteligências, desenvolvimento de habilidades de pensamento crítico, diálogo, resolução de problemas, projetos de desenvolvimento, periódicos instigantes, portfólios etc., podem ser excelentes estratégias de aprendizagem, visto que são consideradas como as abordagens mais adequadas para a comunicação e ensino de línguas estrangeiras. Além disso, o desenvolvimento da competência comunicativa de línguas estrangeiras implica 0 desenvolvimento de todas as habilidades de forma equilibrada: linguística, semântica, sociolinguística, pragmática, fonética etc.

O professor deve gerar um plano sistemático de situações de aprendizagem de forma a promover o desenvolvimento de habilidades em alunos cuja língua materna não é o português. Para esta pesquisa, as variações linguísticas são importantes e essenciais no ensino-aprendizagem, o que inclui estrutura, forma, tempo e espaço em uma linguagem de comunicação falada ou escrita que busca aperfeiçoar. As variações linguísticas fornecem um espaço de apoio e oportunidades para explorar, experimentar e interagir em situações com pessoas e materiais que são relevantes. Níveis de desenvolvimento e diferenças individuais devem fornecer o progresso autêntico na aprendizagem para obter uma avaliação. A educação deve girar em torno da atividade específica dos materiais apropriados como elementos essenciais para 
desenvolver o conhecimento das variações linguísticas da língua-alvo, neste caso, o português.

No nosso caso, usar a música lúdica é uma maneira ideal de estimular o desenvolvimento cognitivo dos alunos e demonstrar dinamicamente o aprendizado. A música oferece muitas oportunidades para atividades criativas, abertas e divertidas que permitem, aos alunos, representar suas experiências e conhecimentos por meio dos diferentes sistemas de performance, isto é, lendo músicas, cantando sem palavras e assim por diante. Também estimula o desenvolvimento de habilidades de pensamento a partir da mediação oral e escrita da linguagem, da pesquisa e da resolução de problemas, entre outros. Em segundo lugar, incentiva a participação dos pais ou amigos, uma vez que são os principais atores no desenvolvimento dos alunos, e, assim, as atividades devem promover uma interação positiva e frutífera no aluno com o seu ambiente social ou com quem vai interagir com a língua.

As variações linguísticas e música são organizadas para integrar completamente os alunos, evitando, dessa forma, a fragmentação, e, dessa forma, são essenciais para promover o desenvolvimento ideal do português como um todo. A distribuição do conteúdo educacional deve garantir um equilíbrio entre os conceitos, processos e atitudes dos alunos. A prática das variações linguísticas no ensino deve garantir o respeito, o apoio e o tratamento apropriado da diversidade dos estudantes e a diversidade cultural dos países de língua portuguesa. As atividades de treinamento devem desenvolver os alunos adequadamente para que possam tomar decisões sobre seu futuro acadêmico, profissional e pessoal. O processo de ensinoaprendizagem das variações linguísticas foi projetado pelos estudantes entrevistados como uma coisa importante, desde que se considere os gostos, interesses, necessidades e problemas dos alunos e a variedade de métodos, materiais, atividades, textos e situações de aprendizagem.

O desenvolvimento da linguagem é essencial para a formação de seres humanos. ensino de compreensão oral das variações linguísticas está relacionado de acordo com a qualidade de habilidades que também são importantes para que os alunos sejam capazes de interagir com outros estudantes em torno dele ou com os nativos 
da língua estrangeira. As noções de leitura e escrita podem ser desenvolvidas em paralelo. Portanto, as experiências sobre métodos e aprendizagem das variações linguísticas devem começar desde o início do estudo da língua estrangeira, pois, assim, os alunos poderão aprender sobre a importância de conhecer as variedades da língua, havendo, então, o desenvolvimento adequado da compreensão oral.

\section{SOLUÇÃO}

\subsection{CRIAÇÃO DO CURSO SOCIOLINGUÍSTICA MUSICAL BRASILEIRA}

Os grupos sociais, em muitas das vezes, são caracterizadas por sua entonação ou variável do nível linguístico. Estes grupos podem ser divididos em classe social, nível de escolaridade, sexo, etnia e esses são componentes que influenciam o modo de falar de qualquer pessoa. Os limites dessas variáveis sociais, em muitas das vezes, não coincidem com os de dialetos geográficos, configurando-se, então, como dialetos sociais que dividem os falantes em componentes da população, distribuídos por todo o alcance geográfico de uma ou mais variantes linguísticas.

O profissional da educação tem que saber reconhecer os fenômenos linguísticos que ocorrem em sala de aula, reconhecer o perfil sociolinguístico de seus alunos para, junto com eles, empreender uma educação em língua materna que leve em conta o grande saber linguístico prévio dos aprendizes e que possibilite a ampliação incessante do seu repertório verbal e de sua competência comunicativa, na construção de relações sociais permeadas pela linguagem cada vez mais democráticas e não discriminadoras (BAGNO, 2006, p. 8).

O curso de sociolinguística musical do português brasileiro é o componente integrador do estudo da língua portuguesa, da linguística e suas variantes, da sociedade e da cultura por meio da música. Corresponde, ainda, a uma abordagem no português brasileiro pelas diferentes regiões do Brasil. Uma estratégia interessante para dar vida à sociolinguística musical é a apresentação de vários cantores de cada uma das 26 
regiões do país, uma vez que essa amostra revelaria as variações linguísticas, a sociedade e a cultura brasileira por meio da música e dos seus cantores. Os objetivos dessa abordagem bem como a sociologia musical pode ser colocada em prática segundo as sugestões de Cumpa (2004).

Uma das lições que os educadores devem aprender com os resultados relatados em pesquisas na área de neurociência é que a eficácia da instrução aumenta à medida que o conteúdo é apresentado não apenas na modalidade verbal tradicional (estímulo hemisfério esquerdo), mas também no modo não verbal ou figural (gráfico, imagem, pictórico ou outro), o que ajudará a estimular o hemisfério direito. Isso leva à necessidade de usar uma estratégia instrucional mista na sala de aula que combine técnicas sequenciais e lineares, com outras abordagens que permitam aos alunos ver padrões, fazer uso do pensamento visual e espacial e lidar com todo o conjunto., além das peças. Nesse sentido, poderiam ser utilizadas as seguintes estratégias de ensino: pensamento visual, fantasia, linguagem evocativa, metáfora, experiência direta, aprendizagem multissensorial e música (CUMPA, 2004. p. 156).

Como variantes linguísticas podem ter elementos fonológicos que formam um sotaque, símbolos, e, também, diferentes distribuições sintáticas, o conhecimento e a utilização de estratégias de comunicação oral ou elementos da mesma oralidade podem variar de acordo com o contexto do falante. O estudo da variação linguística do Português na sala de aula de língua estrangeira é essencial, visto que reflete, diretamente, no agrupamento social, cultural e na internacionalização desse falante. As variações, também, explicam e determinam a forma e o uso de linguagem pelos falantes dos mais diversos grupos sociais. A sociolinguística musical é o componente integrante do ensino-aprendizagem do português brasileiro, da linguística e suas variantes, da sociedade e da sua cultura. 


\subsection{BLOGUE SOCIOLINGUÍSTICA MUSICAL BRASILEIRA}

A pesquisa propôs e elaborou um blog para colocar em prática a sociolinguística musical para o ensino de língua portuguesa e das suas variações. Ele revela a missão, a visão, os objetivos, imagens e atividades para o ensino de língua portuguesa para estrangeiros, aqui, no caso, falantes de espanhol que desejavam aprender a língua portuguesa. A configuração do blog será mais bem explorada neste capítulo, a fim de que outros professores possam, de alguma forma, inspirar-se e colocar em prática a sociolinguística musical.

Figura 1: Componentes do curso Sociolinguística musical brasileira

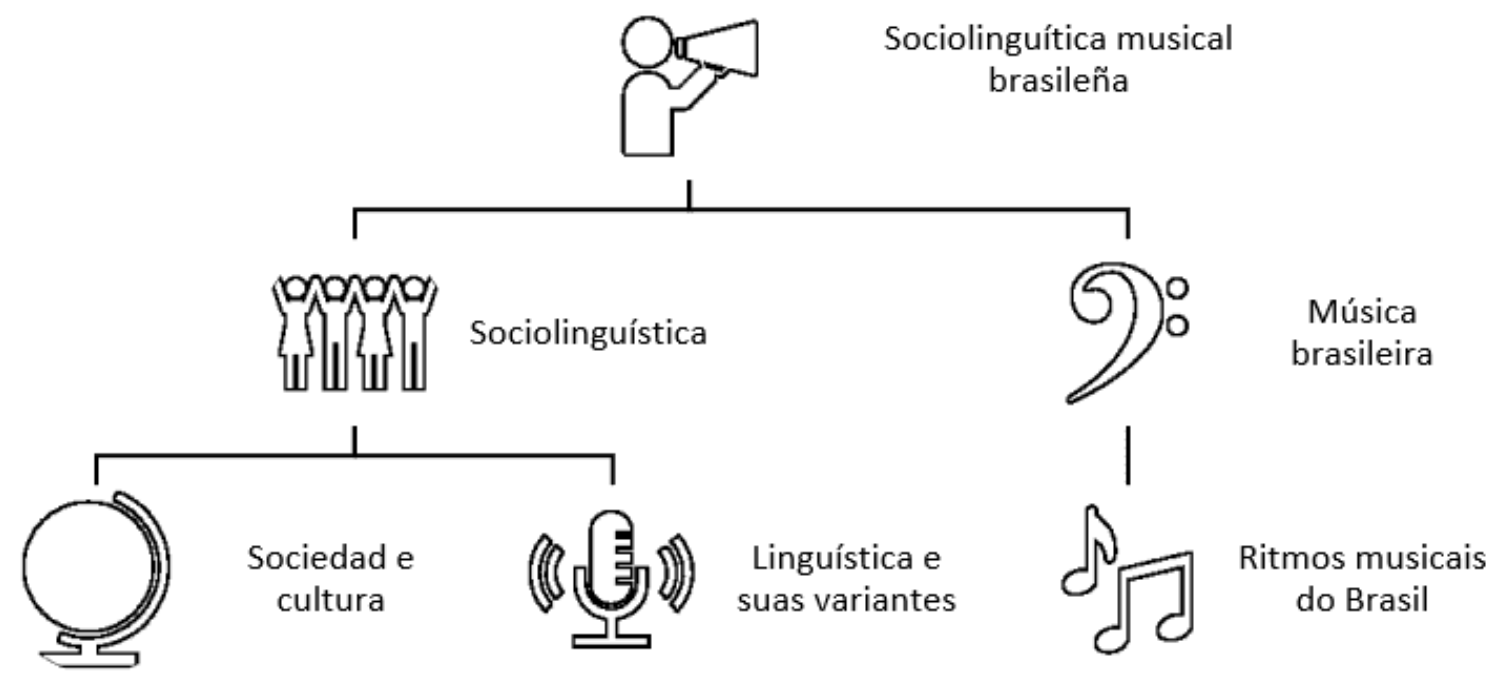

Fonte: Elaborado pelo autor (2020) 
Figura 2: A Sociolinguística musical vista desde a neurociência
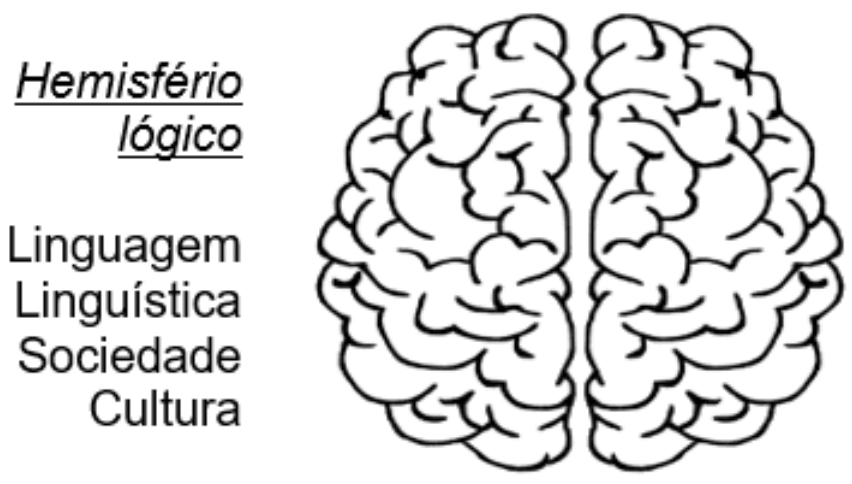

Hemisfério

$\underline{\text { holístico }}$

Música

Canto

Expressão artística

Criatividade

Fonte: Elaborado pelo autor (2020)

Missão: Este curso está desenvolvido para tornar a música brasileira o principal foco de influência e otimização do aprendizado de português, da linguística e suas variantes, da sociedade e da cultura brasileira.

Visão: Treinar o aluno para que adquira habilidades sociais e linguísticas e incentivar e apoiar o crescimento pessoal e profissional deste ao estar em contato com o português do brasileiro.

Objetivos do curso:

Ao término do curso o estudante deverá:

1. Identificar termos políticos e religiosos como vocabulário fundamental para o desenvolvimento linguístico do português brasileiro.

a. Usará o vocabulário aplicado na música brasileira para entender e interpretar os contrastes sociais que marcaram vários movimentos políticos;

b. Reconhecerá a importância de vários aspectos religiosos para o desenvolvimento da sociolinguística musical brasileira; 
c. Exporá a influência da política e da religião no desenvolvimento da sociolinguística musical brasileira.

2. Compare e contraste o impacto dos gêneros musicais brasileiros com a moda contemporânea.

a. Identifique os figurinos como um símbolo representativo em vários gêneros musicais;

b. Reconheça ideias específicas do figurino;

c. Relacione o uso de vários figurinos com a exposição da sociolinguística musical brasileira.

3. Identifique a conexão entre economia e saúde por meio da análise da sociolinguística musical brasileira.

a. Interprete o valor social a partir da música brasileira;

b. Classifique vantagens e desvantagens de acordo com o nível econômico expresso na música brasileira;

c. Distinga benefícios econômicos.

4. Desenvolva a apreciação cultural demonstrando o conhecimento adquirido a partir de várias atividades recreativas e musicais.

a. Incorpore, em seu desenvolvimento cognitivo, os fundamentos da gastronomia para entender o funcionamento sociocultural do Brasil;

b. Integre aspectos voltados aos costumes e tradições da sociolinguística musical brasileira em sua exposição;

c. Identifique elementos básicos das variações linguísticas do português do Brasil por meio de diferentes gêneros musicais. 
5. Colete informações qualitativas e quantitativas para a análise de problemas sociais relacionados à segurança brasileira.

a. Entenda que a implementação do bem-estar social é essencial para o desenvolvimento da segurança;

b. Identifique características regionais para entender estratégias de segurança e atendimento aos diferentes eventos de música cultural no Brasil;

c. Valide a importância da proteção sociocultural representada na música brasileira.

Gráfico 9: As regiões do Brasil

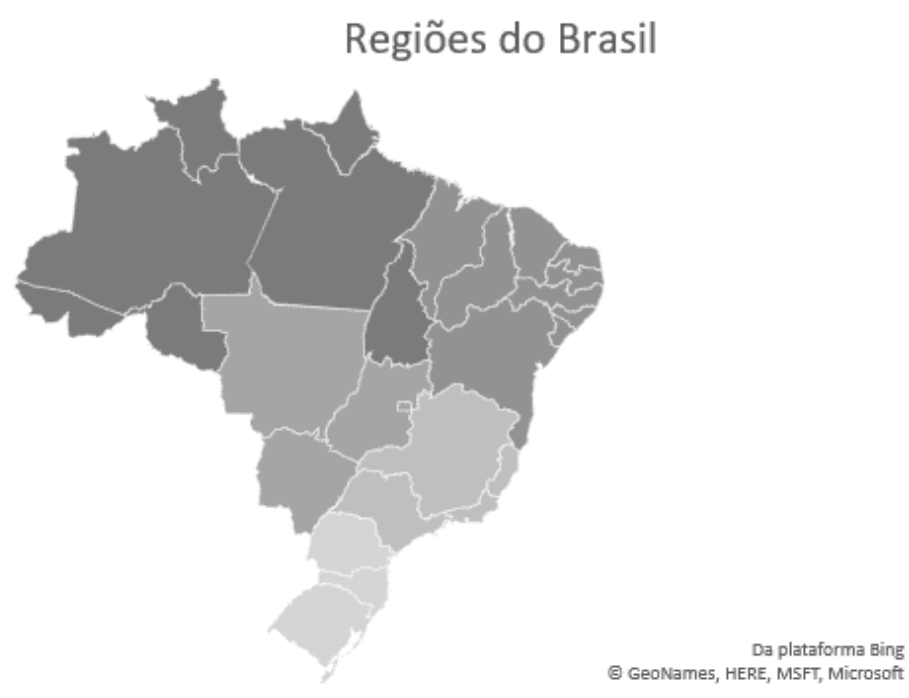

Região Norte

Região Nordeste

Região Centro-Oeste

Região Sudeste

Região Sul

Fonte: Elaborado pelo autor (2020) 
Gráfico 10: Ritmos musicais do Brasil

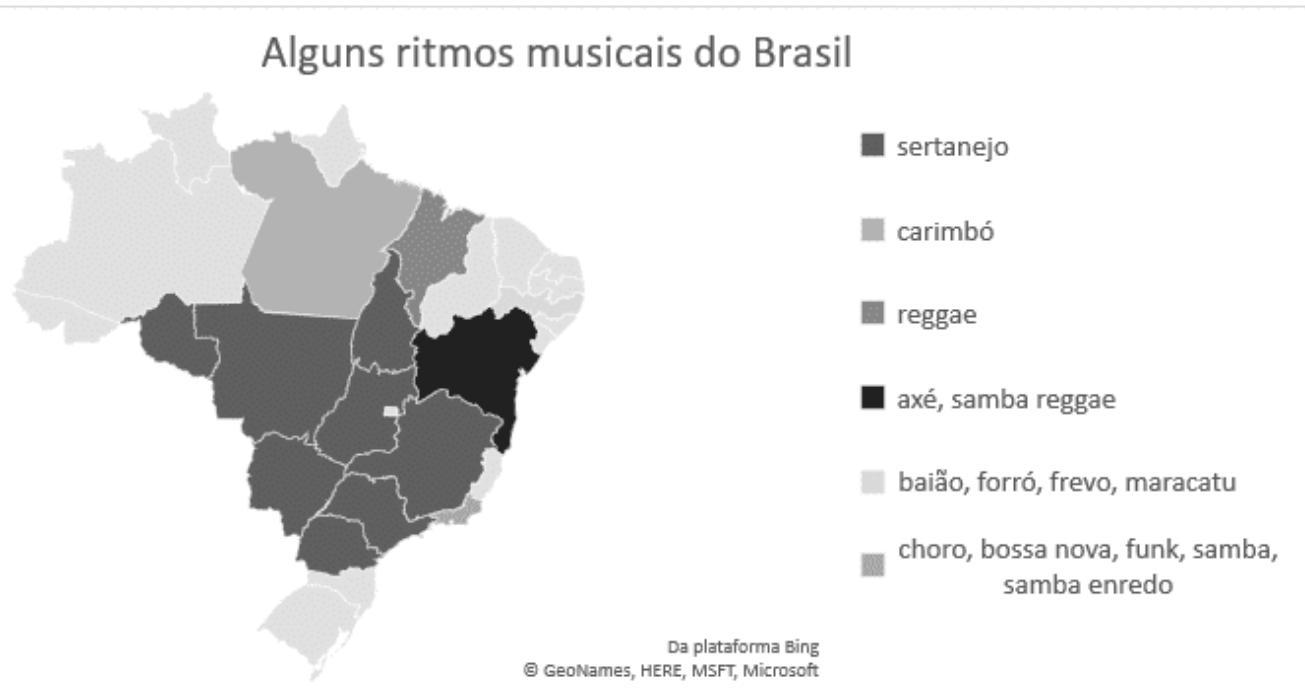

Fonte: Elaborado pelo autor (2020)

\subsection{ESTRATÉGIAS DE ENSINO-APRENDIZAGEM}

Em resposta à tendência para a globalização, a educação é organizada em sequências, unidades e lições temáticas que aparecem como um método completamente unificado para organizar e transmitir as habilidades necessárias na prática escolar. Assim, as diferentes tarefas que o professor realiza com um grupo específico de alunos, envolve a determinação do que precisa ser ensinado e os procedimentos de ensino-aprendizagem que podem ser trabalhados com cada aluno. Isso é essencial para que os conhecimentos diversos das disciplinas propostos pelos currículos escolares sejam aprendidos efetivamente e para que os desenvolvam habilidades fundamentais para a formação de sua personalidade, para que, assim, sejam capazes de realizar uma série de atividades com valor educativo. Um aspecto importante na concepção das unidades está ligado à otimização do tempo de aprendizagem e, assim, deve haver o desenvolvimento de sequências de ensino e de trabalho ao final de cada lição de aprendizagem. 


\subsection{CURRÍCULO DO CURSO}

Atualmente, os currículos universitários não são suficientes para que os alunos tenham uma boa compreensão oral do sotaque do português brasileiro, pois existem variantes linguísticas da língua. As gravações de áudio do método são feitas a partir do idioma padrão. Neste caso, a primeira dificuldade apresentada para este nível de alunos é a compreensão oral da língua devido às suas variedades de sotaques e entonações, devido à região, ao nível social, e ao nível académico dos oradores, sejam eles falantes nativos ou estudantes da língua ou falantes de português. A partir da análise dos dados coletados na pesquisa e avaliados nos gráficos é possível observar que os resultados apontam a necessidade dos alunos de português língua estrangeira de estarem em contato com um curso que prioriza as variações linguísticas para melhorar a compreensão oral dos sotaques do português brasileiro.

Tomou-se a decisão de integrar, no curso, canções que foram gravadas por falantes brasileiros de diferentes partes do país. O uso de música para atividades que desenvolvem habilidades de comunicação verbal e produzem comunicação efetiva tem se mostrado útil para o reforço e compreensão oral de variedades linguísticas. O método musical permite, ao aluno, conhecer e analisar as diferenças que existem na pronúncia ou na entoação oferecidas nas palavras expressas pelos lusófonos de diferentes regiões ou localidades, mas que, em síntese, favorecem a mesma ação de expressar-se. Quando os alunos participam repetidamente dessa prática musical, reforçam sua compreensão, ampliam seu intelecto e ganham a segurança para se desenvolverem livremente em cenários da vida real que exigem a implementação de vocabulários e expressões que compreendem o uso das variações linguísticas.

\subsection{ORGANIZAÇÃO DO ENSINO-APRENDIZAGEM}

- Contexto: Os alunos irão trabalhar com atividades orais e escritas para desenvolver seus conhecimentos e usar corretamente o vocabulário temático. Além disso, pode-se trabalhar com diferentes níveis de pensamento crítico e ser capaz de aplicar esse conhecimento em uma atmosfera real, seja na sala de aula, em uma viagem ou na vida diária; 
- Léxico: O vocabulário é contextualizado com as músicas temáticas, e, assim, serve para que os alunos estejam em contato com os diferentes ritmos musicais espalhados pelas 5 regiões do Brasil, adquirindo, portanto, novos vocabulários e expressões;

- Gramática: Integração dos tempos verbais e conjugações para que sejam trabalhados nas diferentes músicas e materiais escritos durante o curso;

- Leitura: Aplicação de estratégias de leitura que permitem, ao participante, entender e executar tarefas com textos autênticos e não técnicos;

- Redação: Aplicação de estratégias de escrita que permitem, ao participante, escrever pequenos artigos relacionados aos tópicos abordados durante o curso;

- Compreensão oral e expressão oral: O curso será ministrado em português e o material de áudio utilizado será autêntico. Isso permitirá que os participantes tenham contato intensivo com o português oral durante as aulas. Além disso, as estratégias de ensino propostas, que se referem à compreensão e expressão oral, buscam oferecer, aos participantes, a oportunidade de se comunicar/expressar, em português, ao longo do curso;

- Sociedade e cultura: O material didático e as estratégias permitirão a constante discussão, reflexão, comparação e contraste de diferentes tipos de aspectos sociais e culturais do Brasil;

- Linguística e suas variantes: Este tópico tem por objetivo evidenciar uma compreensão básica da variação linguística na língua portuguesa. Um dos principais interesses é criar a consciência nos alunos acerca dos diversos sotaques existentes no português brasileiro e a importância de se conhecer a variação linguística da língua portuguesa. Os alunos devem fazer perguntas que estimulem o processo de sua educação na língua alvo, seja L1 (língua materna) ou L2 (língua não materna);

- Pronúncia: Controlar o tom usando palavras simples e frases com a entonação e pronúncia corretas, dependendo da situação e do ambiente em que o aluno está, e, também, é necessário praticar a produção oral das palavras estudadas que possuem variações linguísticas na compreensão oral do sotaque do português brasileiro da música a ser selecionada; 
- Música: Descobrir uma música e usar o registro escrito desta para que os alunos lembrarem e cantem, e, assim, desenvolvam habilidades de leitura, de produção oral, de interação oral e de compreensão oral acerca das variedades linguísticas dos sotaques do português brasileiro, para, assim, ampliar o conhecimento da sociedade e cultura do Brasil por meio da música é um exercício fundamental;

- Recurso musical: Disponibilizar uma lista de cantores brasileiros por região (vídeos musicais);

- Antes da música: Ativar o conhecimento prévio dos alunos sobre o léxico a ser estudado;

- Durante a música: Leia em voz alta para que os alunos modelem a pronúncia de palavras e para que se sintam motivados a colocar em prática as variedades linguísticas. Forneça, também, atividades que permitam, aos alunos, aplicar e monitorar estratégias de realização, detectar um padrão consistente a partir da leitura de palavras e frases e trabalhe a compreensão oral de variedades linguísticas de sotaque do português brasileiro. Os alunos podem trabalhar em pares para praticar a pronúncia;

- Após a canção: Envolva os alunos em atividades que possam ativar o seu conhecimento. Proporcionar oportunidades aos estudantes para avaliar suas estratégias de compreensão e uso é essencial. Inclua oportunidades para os alunos nas quais eles possam expandir ou desenvolver ideias a partir dos recursos disponíveis no curso e por meio da internet;

- Após a aula: Realize o processo de análise. Esta atividade assume um papel formal e importante, visto que visa a apropriação sistemática e reflexiva dos meios linguísticos que são necessários para a realização de cada atividade e lição. A coerência das sequências é organizada metodologicamente, e, assim, todas as lições correspondem a situações educacionais tratadas em classe e oriundas da vida cotidiana. O método proposto para todas as atividades a serem trabalhadas também contém apropriações gramaticais sistemáticas relacionadas às atividades de comunicação. Esta organização vai ajudar os alunos a compreenderem, efetivamente, português brasileiro, transformando, então, a aprendizagem em um processo lúdico e divertido. 


\section{CONCLUSÃO}

A compreensão oral das variações linguísticas é, portanto, essencial para o desenvolvimento bem-sucedido de cada ferramenta individual. Ao nosso redor, devemos realizar um processo de compreensão auditiva, tomar decisões e desenvolver-nos livremente. Nos tempos atuais, a aquisição de habilidades voltadas à compreensão oral para alunos com deficiência intelectual também é importante. $O$ professor deve trabalhar com a mesma relevância e missão que os alunos de instrução regular. Nós não podemos separar ou limitar os alunos de educação especial, pelo contrário, devemos tomar medidas específicas e individuais para ajudálos. Com este curso, pretende-se aplicar, de modo personalizado, sequências educativas que respondam às necessidades de alunos com dificuldades e com diferentes competências enfatizando, neste caso, a compreensão oral das variações linguísticas do português brasileiro.

Propõe-se a criação de materiais complementares para o ensino-aprendizagem das variedades linguísticas. Devemos integrar as diferentes músicas regionais e começar com tarefas de análise simples, contendo exemplos representativos, curtos e marcantes. O vocabulário é usado para organizar as ideias. Além disso, é preciso estabelecer tarefas para compreensão oral com perguntas claras e respostas simples. As tarefas são atribuídas, identificadas e classificadas como eventos, histórias, diálogos, apresentações, permitindo, então, que os alunos tirem suas próprias conclusões sobre os temas aprendidos. Se forem oferecidos, aos alunos, esses recursos, eles poderão ter sucesso, uma vez que contarão com um processo de aprendizado que evidencia a compreensão oral das variações linguísticas. No ensinoaprendizagem de línguas estrangeiras é necessário quebrar o estigma de que deve haver uma pronúncia "correta" para quem não conhece as variedades linguísticas da língua.

O educador precisa mudar os métodos se apoiando, para isso, no aprendizado cooperativo. Um método deve ser criado para incentivar os alunos a usar uma variedade de textos, áudio, vídeo etc., para que, assim, a sua consciência sobre a diversidade linguística seja aumentada. O ensino-aprendizagem das variações 
linguísticas deve ser feito por meio da música, que é comunicativa e funcional, pois, assim, os alunos terão a oportunidade de usar a língua na sala de aula com seus colegas e com os professores antes da sua futura imersão. Este é o objetivo final: aprender as variações linguísticas da língua portuguesa. Para tanto, é necessário fazer bom uso da linguagem baseada na compreensão oral e nos seus componentes de maneira formal. Este método considera o ensino de línguas estrangeiras do ponto de vista habitual, levando em consideração a prática da diversidade linguística.

Segundo Guy e Zilles (2006), a conclusão dessas observações é que a variação da linguagem está presente em todos os aspectos da linguagem e deve ser levada em consideração por qualquer programa de aprendizagem de línguas. Essa é a realidade linguística que faz parte da experiência de cada falante e, dessa forma, não adianta fingir que a linguagem é homogênea quando estamos na sala de aula com os alunos. $O$ treinamento em idiomas deve ser sensível às diferenças socioculturais, incluindo a variação linguística. O Quadro Europeu Comum de Referência para Línguas e os Padrões Nacionais de Porto Rico contribuiu para com a padronização de ferramentas que fornecem vantagens competitivas e, assim, evidenciam uma estratégia de padronização para fortalecer a capacidade da organização para adicionar valor e interesse pessoal no processo de ensino-aprendizagem. A abordagem básica é começar com um processo de ensino que define níveis específicos, progressão e avaliação.

O PRCS (2014) defende que a aprendizagem deve ser justa e equilibrada para que cidadãos melhores e mais motivados sejam formados, e, assim, traz novos desafios para um mundo pautado na diversidade linguística, social e cultural. Outro sistema usado é a tarefa de "avaliação". É uma ferramenta usada para cada habilidade e tema de aprendizagem. Esse tipo de avaliação nos permite analisar o progresso de cada aluno e construir desenvolver as habilidades necessárias. Quatro habilidades são essenciais para o curso de língua: compreensão oral, compreensão escrita, produção oral e produção escrita. Também é adicionada uma quinta habilidade chamada "metodológica" e ela incentiva a aquisição de estratégias de interação (oral e escrita) (Bailly; Cohen, 2006). A interação oral e a compreensão oral das variedades 
linguísticas nos ajudarão a alcançar uma melhora positiva nos erros encontrados durante o processo de aprendizagem a partir de um método divertido e orientado para a captação do interesse dos alunos de português.

Diversas técnicas podem ser utilizadas para atingir o objetivo básico das variações linguísticas nas quais os alunos aprendem a articular sons e fonemas corretamente combinados. Para isso, pode-se utilizar as seguintes técnicas: imitação e reprodução de sons naturais na língua, simples trava-línguas, repetição de frases com diferentes entonações, palavras diferentes, ritmo rápido ou lento e as canções. As tarefas devem ser úteis e fornecer, aos alunos, razões convincentes para a realização de seus conhecimentos ao final de cada atividade. As atividades devem ser justas e os alunos devem aprender diferentes habilidades apropriadas à sua idade, hábitos e costumes. Os professores precisam de alguma liberdade para adaptar o trabalho propostos pelos livros didáticos. Exercícios mecânicos não devem ser os únicos utilizados nas atividades individuais e em grupo. Recomenda-se a utilização de várias tarefas e técnicas de aprendizagem centradas, principalmente, na abordagem de ação.

Uma perspectiva orientada para a ação é composta por um quadro de referência para a aprendizagem, pelo ensino (e avaliação) de línguas modernas, pela transparência e coerência das atividades, pela abrangência das tarefas e representações diversas do cotidiano. A perspectiva desse estudo parte de ações que consideram o usuário e o aprendiz de uma linguagem como atores sociais que precisam executar tarefas (que não são apenas linguísticas) em circunstâncias diversas, em ambientes distintos e em uma determinada área de ação. Se os atos de fala são realizados a partir atividades linguísticas, estes são parte de ações em um contexto social que Ihes atribui significados. Existe uma "tarefa" na medida em que a ação é o resultado de um (ou mais) sujeito (s) que mobilizam estrategicamente as habilidades que ele (a) possuem para alcançar um resultado determinado. A perspectiva de ação também leva em conta o cognitivo, afetivo, volitivo e todas as capacidades que 0 ator social possui e implementa (CEFR, 15).

Qualquer habilidade aplicável que vise ensinar exige vários fatores. A aplicação apropriada pode ser benéfica para o desenvolvimento bem-sucedido de todo ser 
humano. Podemos provar, cientificamente, que qualquer processo de aprendizagem é eficaz, relevante e pode ser aplicado, entretanto, exige dedicação, determinação e a elaboração de uma sequência pedagógica por parte do professor e a administração educativa, seja este ambiente a escola ou a universidade. $O$ ensino de línguas exige que o professor e o aluno estejam praticando, e, assim, aprendendo continuamente. Não se pode adquirir conhecimento quando se usa argumentos como a falta de tempo para praticar a pronúncia, para realizar exercícios e para imitar modelos como gestos, expressões faciais, reações faciais e quaisquer outros que podem contribuir para a compreensão e absorção de conceitos.

Precisamos fazer tudo o que pudermos para transformar a educação ao nosso redor, ou seja, para entender o que estamos planejando. A abordagem do projeto do professor deve ser linear e paralela ao que deseja alcançar com os seus alunos. Tudo isso é feito com dedicação. Segundo o QECR, é possível aceitar a ideia de que o currículo educacional não começa, não termina e não se limita à escola. Isso implica em admitir que a competência plurilíngue e pluricultural pode dar origem à construção antes mesmo da escolarização e em paralelo com a escolaridade, ou seja, a partir das situações cotidianas, das histórias, das, viagens, da expatriação e da imigração esses alunos podem adquirir conhecimento, visto que pertencem a um contexto plurilíngue e pluricultural.

Essas considerações nos levam a crer que, ao aprender uma língua, no contexto escolar, pode haver a necessidade de reconfigurar os objetivos do curso devido ao contexto linguístico, social e cultural dos alunos, assim, deve-se considerar os objetivos dos programas educacionais de várias línguas para que a diversidade não seja perdida no ensino-aprendizagem de língua portuguesa como língua estrangeira. Para isso, criar um currículo que abrange tal diversidade é essencial. Espelhar-se no Quadro Europeu é uma boa alternativa para respeitar os aspectos linguísticos, culturais e sociais da língua materna desses aprendizes. O Quadro Europeu Comum de Referência para Línguas e o "Porto Rico Core Standards" trouxeram ferramentas voltadas à padronização implementar uma estratégia de padronização para, assim, adicionar valor e interesse pessoal no processo de ensino-aprendizagem. 
Recomenda-se começar com um processo de ensino definindo a partir de níveis específicos, de forma a enfatizar a progressão e a avaliação, pois, assim, haverá uma aprendizagem justa e equilibrada e será possível formar alunos mais críticos e conscientes acerca dos novos desafios do mundo moderno, prezando-se pela diversidade linguística e cultural. Outro sistema utilizado é a tarefa de " avaliação ", uma ferramenta frequentemente usada desenvolver as habilidades e os temas de aprendizagem. Esse tipo de avaliação nos permite manter o treinamento e a avaliação contínua de cada aluno, fortalecendo, assim, todas as habilidades necessárias. Existem quatro habilidades essenciais: compreensão oral, compreensão escrita, produção oral, produção escrita. A aquisição de estratégias para a interação oral e escrita também deve ser enfatizada.

As tarefas devem ser úteis e fornecer, aos alunos, razões convincentes para a realização de seus conhecimentos ao final de cada atividade. As atividades devem ser justas e os alunos devem aprender diferentes habilidades apropriadas à sua idade, hábitos e costumes. Os professores precisam de alguma liberdade para adaptar o trabalho propostos pelos livros didáticos. Exercícios mecânicos não devem ser os únicos utilizados nas atividades individuais e em grupo. Recomenda-se a utilização de várias tarefas e técnicas de aprendizagem centradas, principalmente, na abordagem de ação. Para concluir, é preciso reiterar que os processos de ensino e aprendizagem de línguas em Porto Rico são concebidos como motivadores e relevantes.

Isso ocorre porque os professores levam em consideração os gostos, interesses, necessidades e problemas dos alunos bem como a variedade de métodos, materiais, atividades, textos e situações de aprendizagem. O desenvolvimento da linguagem é essencial para a formação de seres humanos. As noções de leitura e escrita podem ser desenvolvidas ao mesmo tempo. Portanto, todas as experiências de linguagem devem começar o mais cedo possível, já no ensino básico. Para isso, o aluno deve aprender as habilidades essenciais para o desenvolvimento de cada língua (compreensão oral/escrita, produção oral/escrita e interação oral), para que, assim, 
seja capaz de compreender a diversidade linguística, as variantes linguísticas, a sociedade e a diversidade cultural por meio do curso sociolinguística musical.

\section{REFERÊNCIAS}

AKKARI, A. Introduction. Les cultures à l'école: entre indifférence et valorisation. Revue internationale d'éducation de Sèvres, n. 63, p. 33-42, 2013.

APPADURAI, A. Diversité et développement durable. Unesco, Diversité culturelle et biodiversité pour un développement durable: table ronde de haut niveau organisée conjointement par l'Unesco et le PNUE le, v. 3, p. 16-19, 2002.

BADIA, A. et al. La percepción de la utilidad de la tecnología conforma su uso para enseñar y aprender. Revista electrónica de investigación educativa, v. 18, n. 3, p. 95-105, 2016.

BAILLY, N; COHEN, M. L'approche communicative. 2006. Disponível em: http://flenet.rediris.es/tourdetoile/NBailly_MCohen.html. Acesso em: 19. fev. 2020.

CUMPA, J. G. Neurociencia Cognitiva y Educación. Lambayeque: Fondo Editorial FACHSE, 2004.

DE L'EUROPE, C. Cadre européen commun de référence pour les langues: apprendre, enseigner, évaluer. Council of Europe, 2003.

DIAS, H. B; BIDARRA, J. Inovar a aprendizagem online do português L2: novos media digitais e o desenvolvimento de tarefas. In: Primeiras Jornadas TicLínguas, Braga, 2010.

DIAS, H. B. Comunicação e cognição no ensino de línguas a distância: das tecnologias multimedia à criação de ambientes de aprendizagem. Comunicação, Cognição e Media, v. 1, p. 1-15, 2010.

FRANCO, C. de. P. A tecnologia no ensino de línguas: do século XVI ao XXI. Letra Magna, v. 6, n. 12, p. 1-14, 2010. 
GAONAC, H. D. Théories d'apprentissage et acquisition d'une langue étrangère . Paris: Hatier, Crédif, 1987.

GARDNER, H. La mente no escolarizada. Buenos Aires: Paidc's, 1997.

GUY, G. R.; ZILLES, A. M. S. O ensino da língua materna: uma perspectiva sociolinguística. Calidoscópio, v. 4, n. 1, p. 39-50, 2006.

MONTEIRO, L. J. O Escopo da Sociolinguística. In: Para Compreender Labov. 2ª . ed. Petrópolis: Vozes, 2000.

PASCUAL, G. et al. La enseñanza recíproca en las aulas: efectos sobre la comprensión lectora en estudiantes de primaria. Psykhe (Santiago), v. 23, n. 1, p. 1$12,2014$.

POMBO, T. S. Weblogs na Educação: uma experiência no ensino e aprendizagem da Língua Portuguesa e das TIC. Actas do Encontro “Weblogs na Educação, v. 3, p. 55-74, 2007.

PUERTO RICO CORE STANDARDS. Estándares de Contenido y Expectativas de Idiomas Extranjeros para Escuelas Especializadas. 2015. Disponível em: https://nilda.files.wordpress.com/2008/09/estandares_de_idiomas_extranjeros.pdf. Acesso em: 15 nov. 2019

RUÍZ, V. del. C. P; ZAMBRANO, A. R. L. C. Estrategias de enseñanza y aprendizaje de la lectura y escritura en educación primaria. Zona próxima, n. 21, p. 1-16, 2014.

SILVA, P. N. da. Manual de Introdução aos Estudos Linguísticos. UFAM: Universidade Federal do Amazonas, 2010.

SOTO, Y. M. Filosofía Educativa Hostisiana. Entre paréntesis. Periódico digital de la Asociación Puertorriqueña de Estudiantes de Periodismo. 2013. Disponível em: http://entreparentesis.com/2013/10/filosofia-educativa-hostosiana/ Acesso em: 13 dez. 2019. 
Enviado: Fevereiro, 2020.

Aprovado: Fevereiro, 2020. 